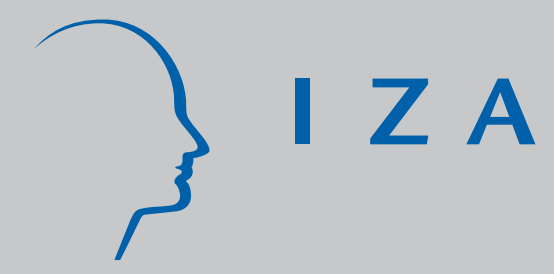

IZADP No. 2016

A Cross-Country Study of Union Membership

David G. Blanchflower

March 2006 


\title{
A Cross-Country Study of Union Membership
}

\author{
David G. Blanchflower \\ Dartmouth College, NBER \\ and IZA Bonn
}

\section{Discussion Paper No. 2016 \\ March 2006}

\author{
IZA \\ P.O. Box 7240 \\ 53072 Bonn \\ Germany \\ Phone: +49-228-3894-0 \\ Fax: +49-228-3894-180 \\ Email: iza@iza.org
}

\begin{abstract}
Any opinions expressed here are those of the author(s) and not those of the institute. Research disseminated by IZA may include views on policy, but the institute itself takes no institutional policy positions.

The Institute for the Study of Labor (IZA) in Bonn is a local and virtual international research center and a place of communication between science, politics and business. IZA is an independent nonprofit company supported by Deutsche Post World Net. The center is associated with the University of Bonn and offers a stimulating research environment through its research networks, research support, and visitors and doctoral programs. IZA engages in (i) original and internationally competitive research in all fields of labor economics, (ii) development of policy concepts, and (iii) dissemination of research results and concepts to the interested public.
\end{abstract}

IZA Discussion Papers often represent preliminary work and are circulated to encourage discussion. Citation of such a paper should account for its provisional character. A revised version may be available directly from the author. 


\section{ABSTRACT}

\section{A Cross-Country Study of Union Membership*}

This paper examines changes in unionization that have occurred over the last decade or so using individual level micro data on twenty seven of the thirty OECD countries, with particular emphasis on Canada, the United Kingdom and the United States. Micro-data is also used to model union membership in a further eleven non-OECD countries. Union density is found to be negatively correlated with level of education in the private sector and positively correlated in the public sector. The probability of being a union member is found to follow an inverted U-shaped pattern in age, maximizing in Canada, the USA and the UK in the mid to late 40s. This inverted U-shaped pattern is repeated in a further thirty countries (Australia; Austria; Bangladesh; Belgium; Bulgaria; Chile; Czech Republic; Denmark; Germany; Estonia; Finland; France; Greece; Hungary; Ireland; Israel; Japan; Luxembourg; Mexico; Netherlands; New Zealand; Norway; Poland; Portugal; Russia; Slovak Republic; Slovenia; Spain; Sweden and Switzerland). I consider the question of why this inverted U-shape in age exists across countries with diverse industrial relations systems including early retirement and cohort effects.

JEL Classification: J3

Keywords: $\quad$ unions membership, OECD, non-OECD

Corresponding author:

David G. Blanchflower

Department of Economics

6106 Rockefeller Hall

Dartmouth College

Hanover, NH 03755-3514

USA

Email: blanchflower@dartmouth.edu

\footnotetext{
* I thank John Addison, Alex Bryson, John DiNardo, Rafael Gomez, Morley Gunderson, Al Gustman, David Howell, Richard Freeman, Geraint Johnes, Tom Lemieux, Craig Riddell, Andrew Oswald, John Pencavel, Craig Riddell, Herb Schuetze and Doug Staiger for help with the data and great comments and suggestions. All errors are mine.
} 
This paper examines changes in unionization that have occurred over the last decade or so using individual level micro data on twenty seven of the thirty OECD countries, with particular emphasis on Canada, the United Kingdom and the United States and builds on earlier work examining the role of unions in the OECD (Blanchflower, 1996). Micro-data is also used to model union membership in a further eleven non-OECD countries (Bangladesh; Bulgaria; Chile; Cyprus; Estonia; Israel; Norway; Russia; Brazil; Latvia and the Philippines).

Over the last thirty years or so Canada, the United Kingdom and the United States have all experienced declining private sector union density - the proportion of private sector wage and salary workers that are members of trade unions. Public sector density in the US has remained relatively constant while it has declined in the UK and increased in Canada. Overall total union density declined in the US and the UK and remained roughly constant in Canada. Union density overall remains higher in Canada and the UK than it is in the US, averaging 30.7\%, 28.8\% and $12.5 \%$ respectively according to the most recent estimates currently available (for 2005 for the US and Canada and 2004 for the UK). There is now evidence that declining density is repeated across most OECD countries although there are still number of countries that have seen increases (i.e. Finland, Iceland, Denmark, Belgium and Sweden) while others have had relatively stable density or small declines (e.g. Norway, Spain and Italy). Such evidence that exists for nonOECD countries is also mixed, although there remains some question about the quality of the data. There is additional evidence from a number of countries that the gap between union membership rates in the public and private sector is substantial and rising over time.

The characteristics of union members show many similarities across the three countries. Density rates are generally higher for men than for women in the private sector but similar in the public, lower for young workers than older workers and, perhaps surprisingly, higher for blacks than whites in the UK and the US; higher in the public sector than in the private sector and higher for full-timers than part-timers. In all three countries union density is negatively correlated with level of education in the private sector and positively correlated in the public; this phenomenon is repeated in many countries both inside and outside the OECD, including countries such as Bangladesh, Israel and Russia. The probability of being a union member is found to follow an inverted U-shaped pattern in age, maximizing in Canada, the USA and the UK in the mid to late 40s. This inverted U-shaped pattern is repeated in a further thirty one countries (Australia; Austria; Bangladesh; Belgium; Bulgaria; Chile; Czech Republic; Denmark; East Germany; Estonia; Finland; France; Greece; Hungary; Ireland; Israel; Japan; Luxembourg; Mexico; Netherlands; New Zealand; Norway; Poland; Portugal; Russia; Slovak Republic; Slovenia; Spain; Sweden; Switzerland and; West Germany). The only countries we did not find evidence that density had an inverted U-shape in age were outside the OECD - the Philippines, Cyprus, Latvia and Brazil. I also find evidence that males have significantly higher density rates in all countries except for many ex Soviet bloc countries (i.e. Bulgaria; East Germany; Hungary; Latvia; Poland; Russia: Slovakia and Slovenia), three from the less developed world (Chile, Cyprus, Israel and the Philippines) as well as Japan, Sweden, New Zealand and Switzerland

First, I report changes in union density across OECD countries for the period 1970-2003 as well as for a number of non-OECD countries such as Argentina, Brazil, Turkey and Taiwan. I then look at a number of macro-economic variables such as unemployment and economic growth and find little correlation with union density. Evidence is found, however, suggesting that countries 
with high union density have lower levels of wage and income inequality. I then examine the various explanations that have been provided for the time series changes in union density rates that have occurred as well as the macro and micro correlates of unionization. Second, I present aggregate data regarding who join unions in the USA, Canada and the UK and document how that has changed over time and space. Third, I make use of rich micro-data files from the three countries for Labour Force Survey, 1997-2005 for Canada; Labour Force Surveys of 1993-2004 for the UK and the Outgoing Rotation Group Files of the Current Population Survey for the US to estimate a series of union membership equations and observe many similarities. Fourth, I report broadly comparable estimates at the level of the individual for many countries using data taken from the International Social Survey Programme (ISSP) files of 2000-2002, the 2002 and 2004 sweeps of the European Social Survey (ESS) and the Eurobarometers of 1988-1994 and 2001 and replicate these patterns. I also report on the desire for unions across countries. Finally, I consider the question of why the probability of union membership might follow an inverted Ushape in age in so many countries with diverse industrial relations systems. I find evidence of cohort effects of union membership in the US and Britain.

\section{Background - changes in unionization rates and its micro and macro correlates}

The background to the changes in unionization rates around the world is that over the last three decades or so there were a series of changes going on that appear to weaken the power of unions that were apparently global in nature (Pencavel, 2005). Product markets have become more competitive. The composition of employment also shifted from highly unionized to traditionally non-union sectors and workers. The share of employment in manufacturing dropped almost everywhere, while the share of employment in white-collar work grew, producing a labor force for whom many traditional union issues were less relevant. Younger workers have shown less interest in joining unions than their parents and their grandparents. The female proportion of employment also rose as did the percentage of part-timers; the level of workers' schooling increased; and the age structure of the workforce changed as the baby boom generation entered the labor market. Labor markets also became increasingly internationalized, as trade was liberalized, immigration increased, and capital markets took on a more global structure. Increased use of profit sharing, some have argued, has also meant that the interests of the employees are increasingly aligned with those of their employers. A major slowdown in world economic growth and productivity and the increased inflation following the 1970s oil shocks, created adverse labor market situations in most countries. Unemployment rates soared, particularly in Europe; unemployment consistent with a given levels of vacancies rose; real wages fell for blue-collar workers, particularly in the US, and unions in several countries took real wage cuts in the 1980 s in order to stimulate employment. ${ }^{1}$

The United States lost its lead in world technology, eliminating a source of potential economic rents for American workers. Kleiner notes that in the US there has also been a "geographical population and employment shift from more union-friendly regions and states in the Northeast and Midwest to states in the South and Southwest which have fewer 'pro-worker' labour market institutions" (2005, p.202). Bennett and Kaufman (2001) note the decline in the amount of effort and resources put into organizing drives. Freeman and Rogers (1999) have argued that pro-

1. An important exception is the UK, where substantial real wage gains were experienced across the wage distribution through the 1980s and 1990s. Katz, Loveman and Blanchflower (1995) provide a discussion. 
worker policies including financial incentives to give voice to workers in non-union environments have lowered the demand for unionization. Bryson and Freeman (2006) compared the preferences of workers in the US and the UK for unions and found that workers in the US have a high and seemingly unfilled demand for unions while a growing proportion of UK workers have chosen to free-ride at union workplaces.

Labor laws in many countries became much less union friendly than they were in the past. ${ }^{2}$ There has also been an increase in overt employer hostility toward unions as measured by increases in violations of US labor laws (Kleiner, 2001). In New Zealand since 1984 the economy was made more decentralized: unemployment benefits were cut, welfare eligibility criteria were tightened, and industrial relations legislation was passed to restructure the industrial relations system by eliminating national awards and removing compulsory unionism. Union density fell dramatically from 40.8\% in 1991 to 24.1\% in 1994 (Maloney and Savage, 1996, p. 201). Kleiner (2005) estimated that the average penalty for violating the National Labor Relations Act in the US is slightly more than $\$ 2700$ whereas the average penalty for a violation of the Employment Relations Act of 1999 in the UK is more than £75,000. This difference Kleiner argues may have a deterrent effect on violations of the Act. Kleiner (2005) goes on to argue that as much as $30 \%$ of the decline in US union density is because of employer opposition policies. Freeman (2005a) argues that "management opposition to unions has been a major factor in the decline in union density in the US". As Flanagan (2005) notes, however,

"there is little or no convincing evidence that the widespread decline in union representation outside of North America can be attributed to increasing management opposition. Nor do labor laws in most of these countries appear to be structured to limit management opposition. Rather the absence of management opposition appears to be related to bargaining arrangements that historically have removed most of the incentives to oppose union representation found in countries with decentralized bargaining arrangements." (2005, p.58)

For all of these reasons one would expect to see unions in retreat across the globe. ${ }^{3}$ That is indeed a consistent story in the major OECD countries (e.g. Australia, Germany, Japan, Netherlands and New Zealand) as well as some countries in the developing world (e.g. Argentina, Brazil, Bolivia, Peru, Mexico and Taiwan) and for most if not all ex-Communist countries (e.g. Hungary, Poland, the Czech Republic, Slovenia and the Slovak Republic) but there are many exceptions (Pencavel, 2005). There are numerous examples of countries that have seen increases in union density rates both in the OECD (e.g. Belgium, Denmark, Finland Iceland and Sweden) and from developing countries (e.g. India, Turkey, South Africa, Chile, Costa Rica, El Salvador and the Dominican Republic). In several other countries union density

2 See Blanchflower and Freeman (1994) for a discussion of the impact of the Thatcher reforms on the British labor market and for more recent evaluations see the various chapters in Blundell, Card and Freeman (2003).

${ }^{3}$ Kelly (2005) has argued that macro conditions for union recovery in Britain have been more favourable recently than they have for many years. He argues that as union organizing drives were getting underway in the 1990s employee discontent was receding and the high degree of political stability with Labour's large parliamentary majority plus party unity, helps explain why there has been no union resurgence. Union drives are only likely to be successful, Kelly argues, when there is a relatively strong sense of injustice and some antagonism to management. 
has been relatively stable (e.g. Norway, Canada, Italy, Panama, Spain and the Philippines). One story clearly will not fit all. As Freeman (2005a) notes though, "unions are mutable institutions that operate differently in different institutional settings".

Figure 1 reports data on the hundred year trends in union density rates in the UK, the USA and Canada. It is apparent that all three countries saw a rising trend with a peak at the end of World War 1 and another at the end of the Second World War. The UK and Canada saw a further increases during the 1960s and 1970s. Both the UK and the US experienced dramatic declines in density since the late 1970s. The US decline started in the 1950s and predates that of the UK that started around 1980 and Canada which started around 1990. As we note below, there have been somewhat different trends in the public and private sectors in the three countries.

Table 1 provides details on union density for 1970, 1980 and 1990-2003 for 20 OECD countries using data drawn from Visser (2006). These data have been adjusted to ensure comparability due to differences across countries primarily because a high proportion of union members in many European countries, particularly, are outside the employed labor force, the denominator usually applied when calculating union density rates. Visser shows that the proportion of members who have retired varies from $4.5 \%$ in Spain to $48.0 \%$ in Italy. Other adjustments are made for unemployed and self-employed. Union density rates declined by at least ten percentage points since 1970 in Australia, New Zealand, Japan, France, Netherlands, Ireland and Switzerland, but increased in six small OECD countries - Iceland, Finland; Sweden; Denmark, Belgium and Spain - while density rates remained roughly constant in Norway, Korea, Italy and Canada. ${ }^{4}$ There is also evidence to suggest that there have been declines in density in many of the former Soviet-bloc countries that have recently joined the EU. ${ }^{5}$

There are some problems in doing cross-country comparisons because there are differences in how the data are collected: some are taken from administrative sources and some from surveys; some countries have unemployed and retired workers included in their estimates (e.g. Canada) and some do not. ${ }^{6}$ Not withstanding all of these caveats it is apparent that the United States' overall level of density is atypical of the OECD. The only countries that look anywhere close to the low US levels of union density are Japan, the Republic of Korea and France. Japan experienced strong declines in density throughout the 1990s and by 2003 less than a fifth of workers were in unions. The Republic of Korea has had low levels of density throughout the period. Even in countries like the UK that have had considerable declines in density over the last

\footnotetext{
4 A recent Statistics Canada report using data from the Labour Force Survey gave slightly higher estimates for Canada although the trends seem to be similar. Union density as a \% of non-agricultural workers, $1991=34.8 \%$; $1992=35.8 \% ; \quad 1993=36.0 \% ; \quad 1994=36.1 \% ; \quad 1995=34 . \% ; \quad 1996=34.3 \% ; \quad 1997=34.5 \% ; \quad 1998=32.7 \%$; $1999=32.6 \% ; 2000=31.9 \% ; 2001=31.3 \% ; 2002=31.1 \% ; 2003=30.4 \% ; 2004=30.4 \%$ and $2005=30.7 \%$ ( $1^{\text {st }}$ January).

Source: M. Bédard (2005), 'Union membership in Canada, - January 1, 2005' Statistics Canada, downloadable at www.hrsdc.gc.ca/en/llp/wid/union_membership.shtml,

5 Visser (2006) reported recent declines in density in Hungary (63.4\% in 1995 and 19.9\% in 2001); the Czech Republic (78.8\% in 1990; 46.3\% in 1995 and 27.0\% in 2001); Slovak Republic (78.7 \% in 1990; 57.3\% in 1995 and $36.1 \%$ in 2001) and Poland (53.1\% in 1989; 32.9\% in 1995 and $14.7 \%$ in 2001).

6. For a discussion of the problems of comparability of union membership data across countries, see OECD (1991).
} 
two decades, the percentage of workers that are members is still considerably higher than it is in the United States (e.g. 12\% in the U.S. in 2003 compared with 29\% in the UK).

Table 2 provides evidence on union density for Latin America and some Caribbean islands. Obviously there are concerns about the quality of these data but they are the best we have so come with a warning to the reader! At least it does appear that the data are recorded in a consistent way over time so that trends may reasonably be analyzed. Density levels are lower in general in these countries than they are in the OECD, but as in the OECD the picture is mixed with some countries experiences increases and others decreases. Since the beginning of the 1980s density has decreased in Argentina, Bolivia, Brazil, Columbia, Ecuador, Guatemala, Jamaica, Mexico, Nicaragua, Panama, Peru and Uruguay. Chile, Costa Rica, El Salvador and the Dominican Republic have seen increases in density rates while rates were stable in Honduras and Panama.

Outside the USA, the UK, Japan, New Zealand and Canada it is frequently the case that workers who are not union members are covered by the terms and conditions of union agreements. This can occur through extension and enlargement provisions both within and outside the bargaining unit. Thus it is necessary to look at coverage rates to get a true picture of the extent of union influence in many countries. Unfortunately it is often extremely difficult to obtain accurate information on coverage as individuals when asked in sample surveys are frequently uncertain, or report wrongly, whether or not they are covered by union agreements. In 2003 only 8.3\% of French workers were union members, although virtually all were covered by union collective bargaining agreements. Although a number of other countries have higher union coverage rates than membership rates - Australia (80\% and 23\% respectively); Austria (99\% and 35\%); Belgium (90\% and 55\%); Finland (95\% and 74\%); Netherlands (85\% and 22\%) none has a density rate of under 20\%. ${ }^{7}$ Bryson (2006) has noted that free riding is also an issue in the UK and especially so in New Zealand. He estimates that thirty five percent of workers in unionized workplaces in Britain and forty five percent in unionized workplaces in New Zealand are nonmembers. The incidence is especially high among managers and supervisors in both countries.

Data are available from the Bureau of Statistics at the International Labour Organisation (ILO, 2006) on changes in density in a number of less developed countries. ${ }^{8}$ Once again it is likely that these data are very noisy and in some the number of employed workers is unavailable so proceed cautiously once again. As is the case in both OECD and Latin American countries some have seen increases in density (e.g. India, Malta, Turkey and South Africa) while others have seen decreases in density (Slovakia, Singapore) or little changed (Columbia; Guatemala; Philippines and Taiwan).

7 Coverage rates are Australia 80\%; Austria 99\%; Belgium 90\%; Canada 34\%; Denmark 69\%; Finland 95\%; France 95\%; Germany 73\%; Italy 82\%; Japan 20\%; Korea 14\%; Luxembourg 60+\%; Netherlands 85\%; New Zealand 21\%; Norway 70\%; Sweden 89\%; Switzerland 37\%; United Kingdom 36\%; United States 15\%; Source: Table 3.3 OECD Employment Outlook, 2004 and Visser (2003).

8 Earlier information was published by the ILO in the World Labour Report, 1997/8. The tables for that report are downloadable at www.ilo.org/public/english/dialogue/ifpdial/publ/wlr97/index.htm 


$\begin{array}{ll}\text { Bermuda } & 1992=22.6 \% ; 1995=24.6 \% \\ \text { India } & 1980=16.7 \% ; 1990=26.6 \% ; 1998=25.6 \% \\ \text { Malta } & 1980=33.2 \% ; 1990=54.0 \% ; 1999=60.8 \% \\ \text { Philippines } & 1980=27.0 \% ; 1990=29.7 \% ; 2002=26.8 \% \\ \text { Singapore } & 1980=26.8 \% ; 1990=15.5 \% ; 2002=22.4 \% \\ \text { Slovakia } & 1996=55.1 \% ; 2000=38.7 \% \\ \text { South Africa } & 1988=39.3 \% ; 1993=57.8 \% \\ \text { Taiwan } & 1989=38.6 \% ; 1995=46.6 \% ; 2003=38.3 \% \\ \text { Turkey } & 1984=53.9 \% ; 1990=55.0 \% ; 1995=69.4 \% ; 2001=58.0 \%\end{array}$

In several other countries union membership numbers are only available and once again the story is mixed. In some countries the numbers of members increased - Guyana (66,516 in 1991 and 70,043 in 1996); Malaysia $(1980=579,266 ; 1990=659,280 ; 2003=789,163)$ and Syria $(312,607$ in 1980 and 595,049 in 2002). In other countries where only union numbers are available there were decreases in the number of members including Pakistan (346,511 in 1980, 359,633 in 1990 and 275,646 in 2001) and Sri Lanka (1,668,230 in 1981 and 640,673 in 2002). It is unclear the extent of coverage in these non-OECD countries, but it is likely low.

Following in this theme, Table 3 reports changes in the numbers of union members in the OECD countries for 1980, 1990 and 2003 or the most recent data available derived from Visser (2006) plus data from eight less-developed countries from ILO (2005) for which there are data for each of these three years. It is apparent that within the OECD the number of union members has declined; among these twenty countries union membership dropped by 26.5 million with the majority of the decline occurring between 1980 and 1990. Between 1990 and 2003 union membership fell by nearly 8 million when civilian employment was increasing in all of these countries except Denmark and Japan: on average OECD employment increased by 11\%. Union membership numbers have been increasing outside the OECD in India, Malaysia, Singapore, Syria, and the Philippines.

Over the last couple of decades trade unions have found it especially difficult to unionize new establishments. Freeman and Kleiner (1990) examined the determinants and consequences of employer opposition to union organizing drives and found that management opposition "had been an important determinant of the decline in unionization". Machin (2000) used data from the 1998 Workplace Employee Relations Survey and found that failure to organize the new establishments that were set up in the private sector in the last twenty years or so "is central to falling unionization” (p. 642, 2000). Disney et al $(1994,1995)$ used data from the first three Workplace Industrial relations Surveys of 1980, 1984 and 1990 and reached similar conclusions. Supporting evidence for this finding is provided by Bryson and Gomez (2005) who report that the decline in union membership in Britain is accounted for by the rising percentage of employees who had never been a member of a union or staff association - which rose from $28 \%$ to $48 \%$ from $1983-2001$.

Pencavel (2003), in a recent examination of the decline of unions in Britain suggested that its cause was the combination of 1) the changed legal environment including the virtual elimination of the closed shop, 2) the abandonment of full-employment macro-policies which meant that organized labor had to operate in a more inhospitable environment 3) the rigors of considerably 
greater product market competition. He goes on to argue that despite what he calls the "surprising retreat of union Britain" there "does not appear to be a pervasive, unmet demand for union representation" (p. 225). Bryson (2003) examines data from the British Worker Representation and Participation Survey of 2001 and confirmed that finding. When non-union members were asked "if someone from the union at your workplace asked you to join how likely is it that you would do so?”, only $10 \%$ said 'very likely' and $26 \%$ said 'quite likely'. Charlwood (2002) found very similar responses in his analysis of responses to the same question in the 1998 British Social Attitudes Survey. However, in a recent study comparing unionism in Canada and the United States, Lipset and Meltz (2004) show that despite the very different trends in union membership between the US and Canada, a lower proportion of workers in Canada than in the US say they approve of unions. For example, when asked if they approved of unions in Canada $55 \%$ of union members and $84 \%$ of non-members agreed compared with $66 \%$ and $91 \%$ respectively in the United States. Riddell (1993) reported similar findings using data from The Canadian Institute of Public Opinion from 1949-1985. ${ }^{9}$ Bryson and Freeman (2006) reported that the Hart Research Associate polls suggested that more than 50\% of non-union workers in the US in 2005 would definitely or probably vote to form a union. In contrast they found in 1998 in the UK $40 \%$ of non-members in non-union workplaces said they would be very likely or quite likely to join a union.

Table 4 reports evidence from the European Social Survey 2002/3 which confirms the finding that there is little unmet demand for union representation in Britain. Respondents in 22 countries were asked the following question. "Please say to what extent you agree or disagree with each of the following statements. - "Employees need strong trade unions to protect their working conditions and wages". Possible responses were - disagree strongly; disagree; neither agree nor disagree; agree; agree strongly. Table 4 reports the results of estimating a series of ordered logits with the dependent variable the responses to the above question; separate equations are estimated for all respondents, non-workers; workers only; union workers and non-union workers. What stands out from the Table is the fact that there is little support for this statement in Great Britain: it is next to bottom in the country rankings, as measured by the size of the country coefficient, with only Denmark having less support for the statement. Respondents from Greece, Hungary, France and Israel are most supportive of the statement. Support is lower the higher the level of schooling and for men, the self-employed and those working.

Support for unions appears to vary by age. In columns 1 and 4 a single age term is included as age squared was always insignificant and hence was omitted. In columns 2, 3 and 5 the age squared term was significantly positive and was included. It appears that for non-workers support for unions rises and reaches a maximum at age 39. For non-union workers it follows a U-shape in age, reaching a minimum at age 53. Support for unions among union members

9 Respondents were asked if they approved of unions in the two countries. The percent reporting a favorable response were as follows (Riddell (1993, Table 4.10):

$\begin{array}{cccccc} & \text { Canada } & \text { USA } & & \text { Canada } & \text { USA } \\ 1952 & 60 & & 1979 & 50 & 55 \\ 1953 & & 75 & 1984 & 51 & \\ 1961 & 62 & 67 & 1985 & & 58 \\ 1978 & 46 & 59 & & & \end{array}$


declines with age. A similar result was found by Bryson and Freeman in their study of the US and the UK. Lipset and Meltz (2004) also found that both in the US and Canada when nonunion workers were asked their voting intentions the young (15-24) in both countries were more likely to say they would vote for a union than older $(25+)$ workers. ${ }^{10}$ This runs contrary to the claims of Shister (1953) who claimed that younger workers are likely to show a greater propensity to unionize because their shorter lengths of service will make them less loyal to their employers. It is also inconsistent with the views of Bain and Price (1983a) who suggest that older workers will have a higher propensity to join because they have fewer opportunities and if productivity declines over time they would have more need for unions.

Bryson and Freeman (2006) create a scalar measure of worker needs for representation that they show is the "single most important determinant of worker desire for unions and collective representation" in the two countries. The needs variable measures problems at workplaces. I am most grateful to Alex Bryson for providing me with additional calculations on the extent to which the workers perceive there are problems at the workplace. He ran a series of equation which only included age dummies; a male dummy; three education variable; a race variable and a constant (not reported). Absolute value of $t$ statistics are in parentheses and the reference category for age is 55+. The dependent variable is their 'needs' variable which is based on 13 responses identifying whether workers reported a problem at their workplace and divided by 13 to form a single scale. Data sources are the US Workplace Representation and Participation Survey (WRPS) and the British Workplace Representation and Participation Survey (BWRPS).

$\begin{array}{lcc} & \text { USA } & \text { UK } \\ \text { Age 18-24 } & 0.020 & 0.013 \\ & (1.51) & (0.73) \\ \text { Age 25-34 } & 0.039 & 0.031 \\ & (3.20) & (1.90) \\ \text { Age 35-44 } & 0.048 & 0.035 \\ & (3.90) & (2.13) \\ \text { Age 45-54 } & 0.044 & 0.047 \\ & (3.28) & (2.80) \\ \text { Observations } & 2049 & 1355\end{array}$

It appears that individual's perceived need for unions is significantly higher in middle age then when young or old. That is to say there is an inverse U-shape in age in the perceived 'need' of having a trade union, which is consistent with the finding of an inverted U-shape in age in union membership probabilities.

Given the time series differences in union density across countries identified above it is likely to be hard to find any consistent macro-correlates and so it turns out. For example, average annual GDP growth over the period 1994-2004 is uncorrelated with changes in density or starting union density. Growth rates and union density from Table 1 are presented below ranked according to

\footnotetext{
${ }^{10}$ Lipset and Meltz (2004) Table 6.6 reported that in their 1996 survey, in the US 60.5\% of nonunion workers aged $15-24$ said they would vote for a union compared with $45.2 \%$ of adults $(25+)$. For Canada the results were $58.5 \%$ and $37.0 \%$ respectively.
} 
1994 level of density and omitting France because of its low density but high coverage. ${ }^{11}$ Correlation between the two series is .028.

$\begin{array}{lcclcc} & \Delta \text { GDP } & \text { 1994 density } & & \Delta \text { GDP } & 1994 \text { density } \\ \text { Iceland } & 3.5 & 87.4 & \text { UK } & 2.8 & 34.2 \\ \text { Sweden } & 2.5 & 83.8 & \text { Canada } & 3.4 & 32.8 \\ \text { Finland } & 3.6 & 80.3 & \text { New Zealand } & 3.3 & 30.2 \\ \text { Denmark } & 2.1 & 77.5 & \text { Germany } & 1.5 & 29.2 \\ \text { Norway } & 2.9 & 57.8 & \text { Netherlands } & 2.4 & 25.6 \\ \text { Belgium } & 2.2 & 54.7 & \text { Japan } & 1.2 & 24.3 \\ \text { Ireland } & 7.9 & 46.2 & \text { Switzerland } & 1.3 & 23.3 \\ \text { Austria } & 2.1 & 41.4 & \text { Spain } & 3.4 & 17.6 \\ \text { Italy } & 1.6 & 38.7 & \text { USA } & 3.3 & 14.9 \\ \text { Australia } & 3.7 & 35.0 & \text { Korea } & 4.9 & 14.5 \\ \text { OECD } & 2.6 & & \text { EU 15 } & 2.2 & \end{array}$

The World Bank has recently argued as follows.

"Union density per se has a very weak association, or perhaps no association, with economic performance indicators such as the unemployment rate, inflation, the employment rate, real compensation growth, labor supply, adjustment speed to wage shocks, real wage flexibility, and labor and total factor productivity." Aidt and Tzannatos (2002, p.11)

There is micro-based evidence empirically, however, that unions reduce employment growth by about 3 percentage points per annum - see Blanchflower et al (1991); Addison and Belfield (2004) and Bryson (2004) for the UK; Long (1993) for Canada; Wooden and Hawke (2000) for Australia and Leonard (1992) for the United States. There is mixed evidence on whether unions impact plant closure (Bryson (2004b); Freeman and Kleiner (1999); Machin (1995); Addison, Heywood and Wei (200); productivity, profitability or investment (Metcalf, 2005; Pencavel, 2004, Hirsch, 2004). DiNardo and Lee (2004) for the US, for example, examined data at the level of the workplace on the impact of unionization on employer business failures/dislocations, employment, output, productivity, and wages and confirmed this finding. They used establishment level data sets that represent establishments that faced organizing drives in the US during 1984-1999. They examined the impact of winning a close election and found the impact on employer survival was small as was the impact of new unionization on wages, employment and output.

A large body of literature claims that unemployment in particular was caused by labor market rigidities in general and trade unions in particular (e.g. Layard et al (1991); Nickell et al (2005) Nickell (1997) and Blanchard and Wolfers (2000)). This was the view taken in the OECD Job Study (OECD (1994a, 1994b). Unemployment is lower in 2004/5 than it was in 1980 in the UK and the US which have seen rapid declines in density. Declining unemployment rates and declining density is also found in Australia, New Zealand, the Netherlands, France, Italy and

11 Source: OECD in Figures. Statistics on the Member Countries, OECD Observer 2005 Supplement 1 
Canada but this pattern is not repeated everywhere. ${ }^{12}$ Unemployment in Japan has increased as union density has declined; the most dramatic evidence of a negative relationship between these two variables is to be found in Denmark that has seen declining unemployment particularly since 1995 and increasing density. Of the four countries with density rates above $70 \%$ - Iceland, Finland, Sweden and Denmark - only Finland has a higher unemployment rate than the OECD average. ${ }^{13}$

Spain is an interesting test case. In 1978, according to the OECD Economic Outlook, 1995 Annex Table 21 Spain had an unemployment rate of $7.0 \%$ while Portugal's was $7.9 \%$. Unemployment in Spain in 1994 was the highest in the OECD (24.2\% compared with an OECD average of $7.7 \%$ ) and considerably higher than Portugal (6.7\%). ${ }^{14}$ There is relatively little evidence for Spain that firing costs, unemployment benefits, unions, the size of the tax wedge (the difference between take-home pay and the cost of labor to employers), skills mismatch, or labor unions had anything to do with the rise in unemployment in Spain over these years (see Blanchflower, 2001) or why unemployment in Portugal remained at low levels while that in Spain ballooned. This runs contrary to claims made in Layard et al. (1991) and repeated in OECD (1994) for the role of these variables. Interestingly in their main unemployment regression Layard et al. (1991) are unable to explain any of the growth in unemployment in Spain, as they simply include in their regressions a dummy variable for Spain for each year since 1973 (Chap. 9, p. 434), which unsurprisingly enters positively and significantly. In 2004 Spain's unemployment rate was $11.0 \%$ (compared with $6.7 \%$ in Portugal) and remains higher than all other OECD members other than Belgium, the Slovak Republic and Poland. As is clear from Table 1, Spain's union density in 2003 was 16.3\%: only the USA and Korea had lower bargaining coverage.

Outside of the OECD there is also no obvious relation between changes in union density and changes in unemployment. We observed rising union density rates in Malta, India, Turkey and South Africa, Chile, Costa Rica, El Salvador and the Dominican Republic and relatively stable rates in Honduras, Panama Columbia; Guatemala; Philippines and Taiwan. Of the eleven countries on this list five experienced declining unemployment rates (Chile; El Salvador; Guatemala; Honduras and Turkey) while six had increases (Colombia; Costa Rica; Dominican Republic; Philippines; Panama and Taiwan). ${ }^{15}$ Of the countries with declining density rates Argentina, Brazil, Bolivia, Columbia, Ecuador, Peru, Taiwan, Trinidad and Tobago and Singapore experienced rising unemployment rates while Chile, Guatemala, El Salvador, Guatemala, Jamaica, Nicaragua had declining unemployment rates.

\footnotetext{
12 Source: OECD Economic Outlook, 57, (1995); OECD Employment Outlook, 2004 Table A and OECD Main Indicators, February 2006

13 Iceland's unemployment rate in 2004 was 3.1\% down from 3.4\% in 2003 according to data from Statistics Iceland. Unemployment was 5\% in 1995, 1.9\% in 1999 and $1.5 \%$ in 2000.

www.iceland.is/economy-and-industry/LabourMarket/nr/74

14 Source: OECD in Figures, 2005 Supplement 1, p.20

15 Source: http://laborsta.ilo.org
} 
There is a growing body of econometric evidence that has now challenged the view that (changes in) union density is correlated with (changes in) unemployment. ${ }^{16}$ Glyn et al (2006) report the results of econometric analyses of the relation between both union density and the nature of bargaining on the unemployment rate across OECD countries and find none. ${ }^{17}$ They also found that that "replacing the union density measure with collective bargaining coverage (the share of employees covered by union bargaining) also produces no statistical association” (2006, p.5).

Over time the OECD also appears to have softened its view. OECD (2004) found that union density was insignificant in cross-country panels where the dependent variable was a) the growth in real GDP per hour worked; b) relative employment of youths; c) the relative employment of older workers and d) the employment rate. Centralization/coordination measures were everywhere insignificant in all of these equations, with or without controls for country fixed effects. The 2004 OECD Employment Outlook argued for "the plausibility of the Jobs Strategy diagnosis that excessively high aggregate wages and/or wage compression have been impediments" to jobs, while admitting that "this evidence is somewhat fragile", while accepting that the effect of collective bargaining "appears to be contingent upon other institutional and policy factors that need to be clarified to provide robust policy advice” (p. 165).

Most recently the OECD itself, in its follow-up to the Jobs Study, appears to have accepted that union density is largely uncorrelated with any macroeconomic outcome (OECD, 2005a, 2005b). For example, over the period 1982-2003 the OECD (2005b, Tables 1.3, 1.7, 1.8, 1.10, 1.11 and 1.8 , for example) finds that in a time-series panel of countries, once country and year fixed effects are included, union density is insignificant in an unemployment equation. ${ }^{18}$ Indeed, the only time it is able to find any effect of union density is when it includes a complete set of interaction terms with variables that don't vary over time (OECD 2005b, Table 1.5), following Blanchard and Wolfers (2000). ${ }^{19}$ Blanchard and Wolfers argued "the interaction of shocks and institutions does a good statistical job of fitting the evolution of unemployment both over time and across countries."20 This result is questionable because it is obtained in an over- fitted model - few data points and lots of variables - and the results appear to be driven by the crosssection variation rather than by any time series changes. That specification tells us little or nothing about whether changes in unemployment in countries such as Spain and Ireland, which

16 Although there is evidence that finds empirically that unions reduce employment growth by about 3 percentage points per annum - see Blanchflower et al (1991) and Addison and Belfield (2004) for the UK; Long (1993) for Canada; Wooden and Hawke (2000) for Australia and Leonard (1992) for the United States.

17 See also Baker et al (2005)

18 OECD (2006a, b) also finds no evidence that employment protection measures have had any effect on unemployment either. As an example the OECD Employment Outlook 2004 showed that Ireland's unemployment t rate fell from $15.4 \%$ in 1992 to $4.6 \%$ in 2003 despite the fact that it had low levels of job protection at the outset on virtually every measure the OECD identified, Ireland's score was unchanged since the late 1980s (Tables 2A.2.12A.2.4).

19 It is for this reason that in Tables such as Table 1.5 in OECD (2006b) time controls cannot be included.

20 See Blanchflower (2001) for more on this. 
experienced rapid increases and rapid decreases in unemployment respectively, had anything to do with changes in union density. Following this theme, the only specifications of the employment rate it reported for men, the OECD (2006b) reported that union density came in positive: higher density is associated with higher employment rates (Table 2.1, column 1). Similarly, the OECD found evidence of a positive effect on employment for females (2006b, Table 2.1, columns 2, 5 and 7) as well as for public employment of the young (Table 2.4, column 6). In large part such weak evidence may simply reflect the difficulty of generating any convincing empirical findings at the macro level because of aggregation and other biases.

A recent paper by Richard Freeman (2005b) has noted how various other international agencies appear to have come round to the view that unions do not seem to raise unemployment. He notes that, the ILO, for example

"takes issue with the view that labour market rigidity has been the major cause of unemployment and that greater labour market flexibility is the solution ... jobless rates appear to have risen independently of levels of labour market regulations ...trade union power was reduced in many countries, together with unemployment benefits and in some cases minimum wages, producing little if any positive employment effect.” (www.jobsletter.org.nz/jbl05210.htm).

The World Bank has stated its position.

"Workers who belong to trade unions earn higher wages, work fewer hours, receive more training, and have longer job tenure on average, than their nonunionized counterparts .... On the other hand, temporary layoffs can be more frequent in unionized firms. At the macroeconomic level, high unionization rates lead to lower inequality of earnings and can improve economic performance (in the form of lower unemployment and inflation, higher productivity and speedier adjustment to shocks)” (World Bank, 2003).

The Inter-American Development Bank now seems to have a similar view.

"Labor regulations are not cost-free, but deregulation is not the answer.... Unions are neither the sand in the wheels of the labor market nor the solution to low wages.... better labor market performance is compatible with lower earnings inequality ... The new agenda requires a strengthened labor authority and a complex network of public and private institutions" (Inter-American Development Bank, 2003 pp 7-8).

Freeman notes that "in short, priors aside, the best summary of the data - what we really know is that labour institutions reduce earnings inequality but that they have no clear relation to other aggregate outcomes, such as unemployment" (2005b, p.12). Freeman (2005a) has noted that "for better or worse, unions and other-wage setting institutions reduce dispersion of pay", (2005a). Aidt and Tzannatos (2002, p.11) have a similar view, that "union density correlates negatively with labor earnings inequality and wage dispersion". Countries with low levels of union density 
appear to have higher levels of inequality. ${ }^{21}$ Card, Lemieux and Riddell (2003, 2004), have pointed to the declines in unionization, as an explanation, for the increase in inequality in the US, the UK and Canada. They find that unions reduced the variance of wages of men in all three countries but find no such evidence for women.

There is evidence to suggest that the impact of unions on the wage front is especially high in the US (Blanchflower and Bryson; 2003, 2004) which in part explains the high levels of employer resistance. After many years of resisting union presence one of Wal-Mart's stores voted to unionize; Wal-Mart announced the store's closure the following day. Blanchflower and Bryson (2003) found that the union wage gap in the United States averaged 18\% for the period 19732001 which was higher than in Canada and the UK and other OECD countries such as Australia, France, Germany, New Zealand, the Netherlands and Spain. They found evidence of a decline in the size of the wage premium in the US since the early 1980s and in the UK since the early $1990 s^{22}$

We now turn to examine micro-data on union members in Canada, the UK and the USA and elsewhere on the characteristics of union members. Despite differences in the proportion of workers who are members of unions or who are covered by collective bargaining agreements or the trends in these variables, there are many similarities across countries in the characteristics of union members in terms of the industry where they work, their race, gender and whether they are employed in the public or private sectors. In particular we find evidence that suggests that the probability of an individual being a union member follows an inverted U-shape maximizing around age 50 in most countries.

\section{Who belongs to unions - facts?}

We start with a comparison of Canada, the USA and the UK. Table 5 provides details of the characteristics of union members in the three countries in 2004 (2005 for the USA). Despite considerable differences in the levels of union density in the three countries there are many similarities in the characteristics of union members and in which sectors they are located. Union density is $\mathbf{2 8 . 8 \%}$ in the UK compared with $12.8 \%$ in the US and $30.7 \%$ in Canada. In all three countries the rates by gender are little different while the membership of blacks is higher than that of whites in the UK and the USA. This is not true of other racial groups - in the UK Indians, Pakistanis and Bangladeshis ('Asians') have relatively low density rates as do Hispanics in the US. The young are less likely to be members of unions in all three countries. Membership rates in manufacturing and construction are lower than average in UK but higher than average in the US. Public sector unionism is higher than in the private sector in all three countries although there is approximately a forty percentage point difference in the UK and Canada compared with just under 30 percentage points in the USA. As we show below, the density rate in the UK has

21 There is also evidence that "earnings dispersion tends to fall as union density and bargaining coverage and centralization/coordination increase", OECD (2004), p.166.

22 The claim made by Metcalf for the UK that "there is now no (wage) benefit to joining a union" (2005, p.92) appears to not be supported by the data. I updated the analysis of Blanchflower and Bryson (2003) and regressed the log of hourly wages on a union status dummy, 60 industry dummies, 20 region dummies, 45 schooling dummies, 5 race dummies, gender dummy and age and age squared using the Fall 2004 Labour Force Survey and found a union wage differential for males of $3.2 \%$ and $12.6 \%$ for females respectively and $8 \%$ overall $(n=14,526)$. 
been falling along with that in the private sector while in the US and Canada the private rate has been declining while the public rate has risen.

Table 5 makes it clear that union density rates rise with age, with relatively low rates when young in all three countries, rise with age and maximize around age 50. They are especially low for those under the age of twenty in all three countries. As we will see below this pattern is repeated across these three countries and many others inside and outside the OECD and remains in a dprobit union membership equations in which includes controls for area, industry, race, gender, sector and education. In the case of Canada Morissette et al (2005) show that unionization rates for the age group 55-64 became lower than workers ages 45-54 only from the end of the 1980s. ${ }^{23}$ The inverse U-shape pattern appears to be a relatively new phenomenon in Canada. Their union density rates are presented below.

$\begin{array}{lccccc} & 1981 & 1986 & 1989 & 1998 & 2004 \\ 17-24 & 26.4 & 17.1 & 18.4 & 11.9 & 13.6 \\ 25-34 & 39.8 & 36.4 & 34.7 & 25.0 & 26.1 \\ 35-44 & 42.0 & 43.3 & 42.9 & 35.8 & 32.8 \\ 45-54 & 41.7 & 43.4 & 44.6 & 42.8 & 41.2 \\ 55-64 & 41.9 & 43.8 & 41.6 & 38.4 & 38.2\end{array}$

Table 6 provides details of changes in overall density rates as well as in the public and private sector by year since 1993 for Great Britain and from 1960 for the US and Canada. Density, in both the private and public sectors, has been down in the UK since 1993. In the US, private density has fallen steadily in almost every year since 1960. In the case of the US public sector, however, density reached its highest level of 40.2\% in 1976 and then has remained more or less steady in the mid thirties since then. In the case of Canada private sector density has declined and, at the time if writing, both the UK and Canada have density rates in the private sector of around $17 \%$, more than double the US rate of $8 \%$.

It is apparent that there are many similarities between Canada, the US and the UK both in terms of the characteristics of union members who are disproportionately male, older and employed in similar industries and in terms of the overall downward trend. Union density remains higher in Britain and Canada than it is in the US. Private sector density continues to decline in all three countries. Public sector density is declining in Britain but is approximately constant in the United States and Canada. ${ }^{24}$ We now turn to model econometrically micro-data on union members in Canada, the UK, the USA and elsewhere.

\section{Who belongs to unions - econometrics?}

\footnotetext{
23 Source Survey of Work History, 1981; Labour Market Activity Survey, 1986 and 1989; Labour Force Survey, 1998 and 2004.

24 Price and Bain (1983) estimate that union density in Britain in 1979 was $43 \%$ in the private sector and $82 \%$ in the public sector.
} 
There have been a series of econometric papers trying to explain the dynamics of union density for a variety of OECD countries. The papers include Hines (1964), Bain and Elsheikh (1976), Bain and Price (1983), Price and Bain (1983a), Carruth and Disney (1988), Freeman and Pelletier (1990), Disney (1990) and Beaumont and Harris (1995), Machin (2000) for the UK; Sharpe (1971), and Borland and Ouliaris (1994) for Australia; Carruth and Schnabel (1990) for Germany; Pedersen (1982) for Denmark; Freeman and Pelletier (1990), Roche and Larragy (1990) and Sapsford (1984) for Ireland; Sharma (1989b) for Malaysia and Singapore; Sharma and Sephton (1991) for Taiwan; Sharma (1989a) for South Korea; Swidinsky (1974) and Kumar and Dow (1986) van Ours (1992) for the Netherlands and Freeman and Rebick (1989) for Japan. For recent surveys see Riley (1997) and Schnabel (2003). A small literature also exists that estimates union membership equations using micro-data for a number of other countries. These include Haberfeld (1995) for Israel and Mulvey (1986); Christie (1992); Deery and De Cieri (1991) for Australia and Schnabel and Wagner (2005) for many countries.

There have been a number of econometric attempts in the literature to explain the low and declining rate of unionization in the US. These have tended to concentrate on structural factors such as the decline in manufacturing and the emergence of a service economy (e.g. Farber, 1985, 1990), employer opposition (Freeman, 1990), inadequate support from the law (Weiler, 1990) and the lack of resources for organization given an exceptionally difficult legal environment (McDonald, 1990). Empirical evidence suggests that the various compositional factors have played but a small part in explaining union decline (see Neumann and Rissman (1984), Farber and Krueger (1992) and Farber (1990)). Moreover, as will be shown in more detail below, other countries which experienced similar structural changes have experienced an increase in union density since the 1950s. The consensus appears to be that while compositional factors play some part, the predominant factor is employer resistance to unions (Freeman, 1988). Compared to Canada, American employers face less legal constraints on their behavior and seem more willing to eliminate union representation or to shift to a non-union environment elsewhere. In comparison with other countries, the US decides union membership in a highly adversarial electoral process at plant level.

Riddell (1993) has analyzed the divergence in the patterns of union density in Canada and the US. He examines five possible explanations: (1) changes in the industrial structure of employment that have split away from more heavily unionized sectors like manufacturing and toward less unionized sectors like services, (2) changes in the legal regimes that encourage unionization, (3) differences in the degree of management opposition (4) changes in the demand for union representation, and (5) differences in public attitudes and value systems towards collective actions. His main conclusion is that differences in the legal regimes and in overt management opposition is the primary cause of the quite separate paths in unionization rates that the two countries have followed. ${ }^{25}$ More recently Lipset and Meltz (2004) have argued that the relative reluctance of employees to join unions in the US compared to those in Canada, is rooted less in their attitudes toward unions than in the US's laissez-faire individualist values compared with Canada's more social democratic tradition. Canadian values, they suggest, are more

25 Riddell (1993) also reports that the differences in unionization rates do not appear to be driven by union wage premiums because they are fairly similar between the two countries - a point we return to below. 
supportive of unions, making them more powerful but this, paradoxically, lowers public approval of unions which Lipset and Meltz show is higher in the US where unions have less influence.

It should be said, though, that there is little consensus in these papers on any single determinant of union growth or decline. There is some evidence that short-run changes in density are positively related to changes in employment and price inflation and negatively related to wage inflation and unemployment (see, for example, Ashenfelter and Pencavel (1969); Bain and Elsheikh (1976); Carruth and Disney (1988); Disney (1990); Carruth and Schnabel (1990)). There is also some evidence for countries other than the US that the declines, as noted above, are also due to changes in the climate in which trade unions operate. Freeman and Pelletier (1990), for example, found that "the vast bulk of the observed 1980s decline in union density in the UK is due to the changed legal environment for industrial relations" (1990, p.156). Unemployment is likely to have the effect of decreasing unionization rates as unemployed workers stop paying membership dues. There is a lot of evidence across countries suggesting that high (local) unemployment weakens workers bargaining power (Blanchflower and Oswald, 1994, 2005a). On the other hand inflation may encourage workers to join unions as they see price increases eroding their real earnings. Employers are more likely to concede wage rises because in times of high and or rising inflation, because these increases can be passed on more easily to customers.

Mason and Bain (1993) surveyed the literature on the determinants of union membership in Britain. They rejected what they called a 'structural determinist' explanation of the decline of unions which emphasized the primary role business cycle, employer policies and government action. They favored an 'interventionist' explanation emphasizing the practices and policies of the unions and the lack of a national leadership committed to growth as a priority. They concluded their review by arguing that "ultimately, the long term health (and indeed survival) of the trade unions in Britain, as elsewhere, depends on developing new approaches in a conscious way, to adapt to and help shape the environment in which trade unions operate, rather than allowing that environment to dictate the future of the trade movement” (p.349, 1993). Unions in the UK have been unable to heed their warning; the environment has been winning hands down.

Bryson and Gomez (2002) have shown that the decline in union membership in Britain is principally accounted for by the rising percentage of employees who have never been union members. They found a significant increase in 'never-membership' in the 1990s relative to the 1980s, and this trend accelerated in the second half of the 1990s. In the economy as a whole, a little over half the rise in never-membership is due to compositional change in the workforce, in that segments with traditionally high rates of never-membership increased their share of employment. The remainder is accounted for by within-group changes. The biggest single factor determining the probability of never-membership was whether or not an individual was employed in a workplace with a recognized union. Employees in unionized workplaces had a 40 per cent lower probability of never-membership than similar employees in non-unionized workplaces. The size of this effect has not changed very much since the early 1980s. Threequarters of the decline in union density within unionized workplaces Bryson and Gomez found was accounted for by a rise in never-membership, suggesting that the rise in never-membership was not simply a function of overt employer opposition or the increasing organizing costs of becoming a member, implied by the rise in non-unionized workplaces. 
What are the characteristics of individuals who belong to a trade union? The starting point for this analysis will be a comparison of the determinants of union membership in the United State States and Britain using two large, broadly similar, data files. The next step will be to extend the analysis to a number of other countries using a variety of data sources.

\section{a) United Kingdom}

A number of papers have modeled the determinants of union membership in the UK using micro-data at the level of the individual. Papers include Stewart (1983); Bain and Elias (1985); Booth (1986); Payne (1989); Green (1990, 1992); Cregan (1991), Elias (1996); Blandon and Machin (2003) and Machin (2004). There is evidence that the probability of membership is higher amongst men, is positively related to age or experience and in some cases is concave in age. There is also some evidence of positive non-white effects and negative education effects. For a discussion see Riley (1997) and Schnabel (2003).

Micro-data at the level of the individual on union membership are available in the UK from the Labor Force Survey every year since 1993. Union data are only reported in one of the four quarterly sweeps of the survey - in the Autumn (September, October and November), of each year. The Labor Force Survey is very similar to the Current Population Survey data we use below for the US which allows us to draw direct comparisons. Here data from the 1993-2004 surveys are pooled, which generates a sample size of just under 711,000 employees. For comparison purposes we also make use of a much smaller survey -- the General Household Survey (GHS) which has equivalent data on individuals available for the single year of 1983. Although the GHS is a time series of cross-sections, 1983 is the earliest year when union status is reported. ${ }^{26}$ Sample size for the 1983 GHS is just over 9000 employees. It is appropriate to determine the probability of a worker being a union member, holding constant their characteristics.

Table 7 reports the results of estimating dprobit models of union membership for the UK. ${ }^{27}$ There are 9075 observations for 1983 but 710,567 for 1993-2004. The sample is restricted to workers only. The dependent variable is set to one if the individual is a union member, zero otherwise. In all equations the following controls are included - age and its square, gender, race dummies, qualification dummies, industry dummies, region of residence dummies and a fulltime dummy. A time trend (1993=0) is included rather than year dummies to determine the ceteris paribus annual rate of decline. Columns 2 and 5 restrict the samples to the private sector while columns 3 and 6 restrict it to the public sector. Column 3 adds 5 further dummies to distinguish the type of public sector organization, with Central Government the excluded category: such data are not available in the GHS. For brevity the coefficients and t-statistics on

\footnotetext{
26 In a recent paper Machin (2004) compared union membership in 2001 using the Labour Force Survey with that in National Training Survey (NTS) of 1975. We do not use the NTS here as it does not contain information on the public sector.

27 Probit analysis is performed here using the dprobit command in the statistical program STATA 9.0 SE. Dprobit reports the marginal effect, that is the change in the probability for an infinitesimal change in each independent, continuous variable and by default, reports the discrete change in the probability for dummy variables.
} 
only higher degree and bachelor's degree are reported compared to the excluded category 'no qualifications' although a full set are included.

The main findings are as follows.

- Men are significantly more likely to be members than women. This contrasts with the results obtained in Machin finds "by 2001 there is no gender gap in union membership" (2004, p. 430) even though the male variable in his Table 2 has a (small) positive coefficient and a tstatistic of 1.75.28 There are no gender effects in the public sector in either time period. ${ }^{29}$

- Blacks have a higher probability of being unionized than whites.

- Overall schooling and qualifications are related positively to membership in the public sector but negatively in the private sector and the differences are big. Individuals with a first degree have a 3.4 percentage point lower probability of being a union member than a worker without formal qualifications in the private sector but a 16 percentage point higher probability in the public sector. This was not apparent in 1983.

- The probability of being a union member rises with age and reaches a maximum in the late 40s (48 using the LFS and 46 from the GHS). When a set of eleven age dummies, each covering five years (e.g.20-24), are included the function maximizes a little higher in the age category 50-54. More details on this are presented below.

- $\quad$ The maximum of the age function has moved up slightly over time from 46 in 1983 to 48 in 1993-2003.

28 I understand from private communication with Steve Machin that the lack of a gender differential in his paper arises because, for comparison purposes, that in Machin (2004) he excluded a public sector dummy because it is unavailable in the NTS. That appears to account for the difference between our two papers; adding a public sector dummy, or detailed industry dummies, produces a significant and positive male differential. Appendix Table 1 presents evidence on the significance of the male dummy in UK union membership equations, using data from the latest data file available at the time of writing, the Fall 2004 LFS. In the first six columns I exclude the selfemployed who are asked about their union membership (in 2004 membership rate $7.9 \%$ compared with $28.7 \%$ for employees) and include them in the final column. In the raw data the unionization rate of women is the same as that of men (Table 5) and that is replicated in column 1 where the male dummy has a negative sign with a t-statistic of 1.75. Once age and its square and race dummies are included the t-statistic falls. Adding schooling dummies the sign now switches to positive with a t-statistic of 1.90; the addition of industry dummies, or a private sector dummy, or both results in a significant and positive male dummy, with a t-statistic in all cases of over eleven. In the final column a significant and positive coefficient results when only a private sector dummy is included. Females are disproportionately employed in the public sector; once account is taken of that fact there is a significant and positive male effect. When the self-employed are included in the final column the results are the same, the male coefficient is positive along with a significant negative coefficient on the self-employment dummy. If one compares the size of the male coefficient in Appendix Table 1 column 5 with the comparable equation in Table 7 it appears that the size of the male coefficient in 2004 (.0635) is actually increasing. The value obtained using the 2004 LFS is higher than was obtained for the period 1993-2004 (.0247 in column 1) or for 1983 (.0310 in column 4).

${ }^{29}$ Note that in 2004 65\% of all workers in the public sector were female compared with $41 \%$ in the private sector (Heap, 2005). Total employment in 2005 in the UK was 28,713,000 made up of 22,867 in private employment and 5,846, or 20.4\% in public sector employment down from 23.1\% in 1992 (Hicks, 2005, Table 1). 
- Union density has declined by nearly half a percentage point a year holding constant characteristics.

- There remains a large public sector differential of more than 40 percentage points.

- Full-timers have higher density rates than part-timers

- The broad patterns observed in the data using the LFS from 1993-2004 are broadly similar to those observed using a much smaller data file from the GHS for 1983.

\section{b) United States}

I now turn to estimating dprobit models of union membership in the US using data from the CPS Merged Outgoing Rotation Group Files of 1984-1991 and separately for 1992-2002 to determine the extent to which the unionized workforce in the two countries is comparable. I use data from the earlier period as background; union data first become available in the MORGs in 1984.30 Information is available on the union status of approximately 1.6 million workers in the first period and 1.8 million in the later period. Even though data are available for 2003 and 2004 I stop at 2002 because of changes in the industry code which make comparisons difficult. The dependent variable is set to one if the individual is a union member, zero otherwise. It is necessary to change the schooling measure in the later period because the BLS switched from a schooling measure to a more credential oriented indicator. In all equations age and its square, full-time status dummy, race dummies, a gender dummy plus controls to distinguish whether the individual worked in the public or private sector as well as state and industry are included. Controls are as similar as I can make them to the controls used in the UK above. Examples of papers for the United States that model the probability of union membership using micro data include Antos et al (1980) and Hirsch and Berger (1984).

Table 8 for the period 1984-1991 includes years of schooling as the education control. Table 9 for the subsequent period includes 15 highest qualification controls; the decision to split the data in two in 1992 arises because of changes in the education question in the CPS in that year. In Table 1 the coefficients on the four highest education categories compared with workers with $<1^{\text {st }}$ grade education are reported - once again the remaining dummies were included but results are not reported. Tables 11 and 12 for the US suggest that the decline in union density has slowed (from 0.36 percentage points per annum in the first period to 0.18). It is also apparent that the broad patterns are similar - by race, gender, full-time/part-time and by education. The main difference between the two tables is that in the first period the trend in public sector density is insignificant but in the second period it turns down. ${ }^{31}$ For brevity only a few selected qualifications and state dummies are reported.

30 For details of the files and to download manuals and the data see www.nber.org/data

31 The results reported here are broadly consistent with those of Bender (1997) who used individual level data from the 1972 and 1987 May CPS files to estimate separate union membership equations for each of these years using a variety of estimation techniques. However, in contrast to the results reported here his sample was restricted to manufacturing only. He found some declines in the gender and age/experience terms over time but overall relatively few significant differences between the estimated coefficients over time. The results were broadly similar whichever 
- Men are more likely to be members than women in both the private and public sectors by between 3 and 4 percentage points.

- Blacks have a higher probability of being unionized than whites.

- Overall schooling and qualifications are related positively to membership in the public sector but negatively in the private sector.

- The probability of being a union member rises with age and reaches a maximum in the late 40s (47 for 1984-1991 and 49 from 1992-2002). When a set of eleven age dummies, each covering five years (e.g.20-24), are included, the function maximizes in the age category 5054. More details on this are presented below.

- As in the UK the maximum of the age function has moved up slightly over time from 47 for the period 1979-1991 to 49 for the period 1992-2002. The age maximum in the US is higher in the private sector than in the public sector in both periods whereas it is the same in the two sectors in the UK.

- Union density has declined by .4 of a percentage point a year holding constant characteristics.

- There remains a large public sector differential of 20 percentage points.

- Full-timers have higher density rates than part-timers

- The broad patterns observed in the data for 1984-1991 are similar to those observed for 1992-2002.

\section{c) Canada}

Table 10 presents the results of estimating a union membership dprobit for employees in Canada using data from the June 1997-December 2005 Canadian Labour Force Survey (CLFS). We make use of data for each year from the June and December samples. Individuals rotate in and out of the Labour Force Survey - they are in for six months and then leave. New rotation groups enter in June and December each year. There is information in the CLFS on unions for all six rotation groups. Once you have data for December and June each year, adding the other months adds very little as essentially the identical information for the same people is repeated. It is not necessary to cluster the standard errors are there are no repeat observations on the same individuals. There are just over 900,000 observations. Controls are included for industry and province and for highest qualification as well as an annual time trend (1997=0) and a December dummy to identify the relevant rotation group. Results are reported overall and separately for the

estimation method was used. Changing socio-demographic characteristics did not have a large effect on the decline in density, which is consistent with the results reported here. Bender's central finding is that gains in educational levels, changing occupations, and reductions in the economies of scale of union organizing activity appear to have played a much more important role. 
private and public sectors. Data on age are only available in bands so 11 dummy variables are included.

It is apparent that the main results for the US and the UK are all repeated here. Males have higher probabilities than females of being union members as does being a public sector worker. There is a 47 percentage point difference between the public and private sector rates. Having a bachelor's degree enters negatively in the private sector and positively in the public sector equation. Workers in the age group 50-54 have the highest probability of being union members in all three equations. ${ }^{32}$ Interestingly there is a no significant overall time trend but a significant negative trend in the private sector and a significant and positive one in the public sector.

Riddell (1993) also examined the similarities and differences in the US and Canada using microdata. In the case of Canada the data source was the Survey of Union Membership $(n=3,995)$ and for the US it was the CPS, both taken in December $1984(n=4,372)$. Controls were a series of age dummies, gender, and industry dummies; controls were not included for education or location. He found evidence in both countries that membership was higher for full-timers, those aged 25-34; men; public sector workers. He included five dummy variables for age in each country and found that they were not significantly different when he estimated a pooled equation and included interaction terms. The probability of membership was higher for the 25-34 year olds than the excluded category of $<25$. The coefficients on the remaining age dummies became progressively smaller but significant. The age 65 and over was insignificant in both countries. Riddell (1993) concluded that 83 percent of the Canada-US unionization gap was due to intercountry differences and only 17 per cent to differences in characteristics.

\section{d) Other countries}

Are the patterns in these data for the UK and the US repeated in other countries? It turns out that many of the findings we have identified are repeated both inside and outside the OECD. Evidence is found that supports the findings that union density is higher in the private sector, is related to age in an inverse U-shape maximizing in the late 40s and is declining.

Visser (2003) reported union density estimates for a number of countries by gender and by sector. We report a selection of countries below from Visser's Table 11.8 where all four estimates are reported. ${ }^{33}$

32 For both the UK and the USA, replacing the age and age squared term with exactly the same age dummies, the maximum also falls in the 50-54 age category. For the USA, when equation 1 of Table 11 was re-estimated for the period 1984-1991 the coefficients were - age 20-24=.035; 24-29=.081; 30-34=.113; 35-39=.133; 40-44=.147; 45$49=.156 ; 50-54=.163 ; 55-59=.169 ; 60-64=.149 ; 65-69=.069 ;>=70=.01(n=1,600,112)$. When equation 1 of Table 12 is re-estimated for 1992-2002 with the same controls the estimated coefficients were as follows: age 20-24=.033; $24-29=.081 ; 30-34=.102 ; 35-39=.112 ; 40-44=.132 ; 45-49=.151 ; 50-54=.159 ; 55-59=.155 ; 60-64=.129 ; 65-69=.055$; $>=70=.030(\mathrm{n}=1,811,934)$. When equation 1 of Table 10 is re-estimated for the UK with the same 11 age dummies the results are as follows: age $20-24=.095 ; 24-29=.166 ; 30-34=.211 ; 35-39=.236 ; 40-44=.259 ; 45-49=.275 ; 50-$ $54=.277 ; 55-59=.273 ; 60-64=.239 ; 65-69=.117 ;>=70=.114(\mathrm{n}=710,567)$.

33 Visser (2003) also reports density numbers only by gender and not by sector in a further 5 countries - Denmark in 1997 (73\% male 78\% female); Ireland in 1997 (44\% and 43\%); Korea in 1998 (15\% and 5\%), Malaysia in 1988 (15\% and 8\%), South Africa in 1994 (32\% and 29\%). He also reports estimates only by sector in another 4 countries - Italy in 1997 (36\% private and 43\% public), Spain in 1997 (14\% and 32\%), Poland in 1999 (10\% and 80\%) and Israel in 1997 (25\% and 50\%). 
Australia (1998)

Austria (1998)

Canada (2000)

Finland (1989)

France (1993)

Germany (1997)

Japan (1995)

Netherlands (1997)

Norway (1995)

Sweden (1997)

Switzerland (1988)

$\begin{array}{lccc}\text { Men } & \text { Women } & \text { Private } & \text { Public } \\ 30 & 26 & 24 & 55 \\ 44 & 27 & 30 & 69 \\ 31 & 29 & 18 & 70 \\ 69 & 75 & 65 & 86 \\ 13 & 7 & 4 & 25 \\ 30 & 17 & 22 & 56 \\ 27 & 16 & 22 & 68 \\ 33 & 17 & 19 & 45 \\ 57 & 58 & 44 & 79 \\ 83 & 90 & 77 & 93 \\ 35 & 12 & 22 & 71\end{array}$

The picture on gender is more mixed than it is in the UK and the US. Male density is higher in eight of these countries but lower in the three Scandinavian countries. In all of these countries, despite differences in the union density levels and in the time series reported in Table 1, there is a positive public sector membership differential. The question is whether this picture remains once controls are included and whether there are other similarities.

Table 11 presents individual level data pooled from 8 years and nineteen different Eurobarometer surveys from 1988-1994 and 2001.34 In total there are nearly 250,000 observations from fifteen European countries including Britain. Data are unavailable on whether the worker is employed in the private sector. All equations include 9 controls for age left school, gender, seven year dummies, age and its square. Individuals of working age are asked whether they are union members including the unemployed and those not in the labor force (OLF). Twenty labor market status dummies are included in each of these equations. The equation in the first row pools the countries and also includes fourteen country dummies. Results in the remaining rows are obtained from separate equations for each country. The 2001 dummy is compared to the excluded year 1988. In all fifteen countries the age and age squared terms were significant (positive and negative respectively) and overall from the pooled country equation the probability of being unionized maximized at age 48 - the unweighted average of the fifteen country estimates was also 47 . In all cases the male coefficient was significantly positive; the 2001 year dummy was significantly negative overall and in thirteen of the fifteen country equations, confirming the finding of declines in density observed in the aggregate data reported in Table 1. The two exceptions were Ireland and Portugal where there was no evidence of significant declines between 1988 and 2001. The results for Britain are consistent with results in Table 7 using the LFS and GHS. The second part of the table restricts the sample to employees to be strictly comparable with the evidence for the US and the UK. Results are consistent with those in part A although the significance is worse, presumably due to the small sample sizes in some countries. The age maximum is a little lower than found when the sample includes business owners, the unemployed and those who are OLF.

34 For details of the Eurobarometer survey series see www.gesis.org/en/dtat service/eurobarometer/index.htm. The data are available through ICPSR. These are the only years that data on union membership are available. 
Table 12 reports the results of estimating union membership probabilities across twenty countries using data from the 2002 and 2004 sweeps of the European Social Surveys (ESS). ${ }^{35}$ In contrast with the LFS, GGHS and CPS surveys used above for the UK the question on whether a respondent was a union member was asked not only of employees but all other individuals but we restrict our sample to workers for comparability with the US, the UK and Canada. In the first column an equation is reported with just over 33,000 workers, while in the second the sample is restricted to the private sector, defined by industry worked and covering health, education and public administration only. The probability of being a union member maximizes out at age 49 overall. The first equation equations include years of schooling and an interaction between schooling and the private sector variable, which shows that union membership is negatively correlated with education in the private sector and positively correlated in the public sector. The findings are confirmed in the private sector results in column 2 where the schooling variable is significantly negative and significantly positive in the public sector. Gender is significantly positive in the private sector but insignificant in the public. As in the US the age maximum is higher in the private sector than in the public.

Table 13 reports the results of estimating a series of country equations using the ESS data for workers and non-workers and finds evidence for seventeen out of twenty two countries that union membership is inverted in age maximizing in the late forties - the exceptions are Austria, France, Italy, the Netherlands and Spain. The age where the probability maximizes is highest in Israel (60) and lowest in Belgium (36). Male enters positively and significantly in eleven countries, negative in three (Finland, Slovenia and Sweden) and insignificant elsewhere. Evidence of a negative effect of schooling in the private sector is found in Denmark, Germany, Great Britain, Ireland, Israel, the Netherlands, Norway and Poland. These findings are similar to those found above for Canada, the UK and the US. They are different from the results of Schnabel and Wagner (2005) who also estimated union membership equations using the first sweep of this data file. They found few consistent patterns across countries but this appears to be driven by the inclusion of a number of deeply endogenous attitude variables such as 'political orientation' and whether a respondent agrees that 'employees need strong unions' which are likely impacted by the individual's union status.

Table 14 uses data from the three most recent years of data available from the International Social Survey Programme (ISSP) for 2000-2002.36 Data are available on 35 countries including Canada, the UK and the USA for a total of just over 48,000 workers. ${ }^{37}$ The table reports the results of estimating union membership probabilities which include limited set of controls - age and its square, gender, two year dummies and a private sector dummy along with a full set of 35

35 Details of the survey and the data are available at www.europeansocialsurvey.org

36 For details of the ISSP survey series see www.issp.org/homepage.htm. The data are available through ICPSR.

37 Australia (excluded); Germany-West; Germany-East; Great Britain; Northern Ireland; United States; Austria; Hungary; Ireland; Netherlands; Norway; Sweden; Czech Republic; Slovenia; Poland; Bulgaria; Russia; New Zealand; Canada; Philippines; Israel; Japan; Spain; Latvia; Slovak Republic; France; Cyprus; Portugal; Chile; Denmark; Switzerland; Bangladesh; Brazil; South Africa; Finland and Mexico. 
country dummies. In all three of these countries, despite the small sample sizes, the interaction between private sector and schooling is significantly negative and the male coefficient is significantly positive. Density is higher in the public sector, is higher for men than women and is positively correlated with years of schooling. The probability of being a union member maximizes out at age 46 overall. When separate equations are estimated for the private and public sectors the finding that union membership is negatively correlated with education in the private sector and positively correlated in the public sector as found in the UK and the US is confirmed here.

Table 15 presents further results from separate regressions that confirm these results for nearly all of the thirty-five countries. The proportion of workers that are union members is reported in the final column, which seems to be broadly consistent with the estimates reported in Table 1 above. Union density is an inverted U-shape in age in twenty-nine countries; the exceptions are Latvia, the Philippines, Brazil, Cyprus and the Netherlands. The country with the lowest age maximum at 27 is Bangladesh and the one with the highest at 64 is Hungary. The unweighted average across these countries is 47 . There are positive male membership differentials in twelve countries, and a significant negative on the years of education*private sector interaction term Australia, Austria, Bangladesh, Canada, Cyprus, Czech Republic, West Germany, Great Britain, Ireland, Israel, New Zealand, Philippines, Poland, Sweden and the United States.

The evidence on union density from the ISSP, Eurobarometers and ESS surveys is broadly consistent with the evidence found for Canada, the US and the UK. Sample sizes are somewhat smaller in the ISSP and the ESS than in the Eurobarometers, where the most consistent evidence is found. In particular it appears that membership is related to age in an inverse U-shape no matter what the level of union density prevailing in the country or whether it is corporatist or not. Where union density is high, in countries such as Sweden, Denmark, Finland and Norway I find little evidence of private sector or schooling effects. Indeed, in Russia, Slovenia, Finland and Sweden there is evidence that females have higher probabilities than males of being union members.

\section{Conclusions}

The paper reports on the declining levels of union density in many countries both inside and outside the OECD. It was noted, however, that there are exceptions; countries such as Sweden, Finland, Norway and Denmark in the OECD and Turkey, South Africa and India have seen increases. It was also noted that private sector and public sector densities have diverged dramatically in most countries, with private sector densities in many countries more than twenty percentage points higher. In many countries public sector density has changed little over the past couple of decades.

It was found that unions at the micro-level were generally successful across countries in raising wages and reducing employment growth but there was little evidence they had much effect on plant closings, productivity, investment or profitability. At the macro level little evidence was found to suggest that higher levels of union density in a country were correlated with unemployment or economic growth or other macro variables. There was also only limited evidence showing any correlation between types of bargaining, degree of corporatism and any 
other macro variable. The one major exception is that countries with higher levels of union density have lower levels of income and earnings inequality.

Evidence was found for many countries that males had higher probabilities of being union members. Schooling was negatively correlated with being a union member in the private sector but positively correlated in the public sector. Support for unions among union members was found to decline with age. Among non-union members support for unions was found to be higher among younger age groups.

The most puzzling result in the paper is the finding that union membership follows an inverted U-shape in age across so many countries with different density levels and trends and types of bargaining. We have micro-data at the level of the individual on twenty-seven out of the thirty members of the OECD and find an inverted U-shape in age in at least one of our data sets for all twenty-seven. ${ }^{38}$ The only exceptions are Turkey, Korea and Iceland where we have no data. We also have the same inverse U-shaped result for Bangladesh, Chile, Bulgaria, Estonia, Israel, Norway and Russia. The only countries we do not find the result are from the developing world: Cyprus; Brazil; Latvia and the Philippines.

The obvious question to ask is why would union membership follow a path that maximizes at around age 50 for so many countries? Given the finding that the pattern operates widely it remains unlikely that the results are going to be driven by country specific factors. A number of possibilities suggest themselves

a) Union members quit their jobs from their late forties and move to non-union jobs in other organizations. This appears to be a possibility especially for workers in the US public sector who are covered by defined benefit pension plans. Members of the NYPD and other unionized police departments around the country are able to retire after twenty years of service with generous retirement packages which include retiree health care benefits. In the case of the NYPD, for example, the pension multiple is derived based on the single highest year of earnings including overtime. As overtime is often determined by seniority the last year of service usually carries with it a lot of overtime which then raises dramatically the amount of the pension. The individual rules of the pension plans determine when this pension can be drawn without penalty.

As an extreme example, most police departments do not pay Social Security for their members although most sheriffs departments and corrections departments do - and hence there is an incentive for retiring union members to move to jobs that do pay Social Security, some of which will be non-union. It remains unclear the extent to which this phenomenon operates in the unionized private sector. It may well be attractive to retire from General Motors in Michigan at age fifty on a sizable pension and then even move, say, to the Right-to-work states of Nevada, Arizona or Florida which have seen large net in-migration in recent decades, and work in a nonunion job at lower pay. Working at a golf course in the winter sun is attractive to some,

\footnotetext{
38 The thirty members of the OECD are Australia; Austria; Belgium; Canada; Czech Republic; Denmark; Finland; France; Germany; Greece; Hungary; Iceland; Ireland; Italy; Japan; Korea; Luxembourg; Mexico; Netherlands; New Zealand; Norway; Poland; Portugal; Slovak Republic; Spain; Sweden; Switzerland; Turkey; United Kingdom and the United States
} 
including the author, when the temperature hits minus 15 Fahrenheit in the frigid North-East! The extent to which this occurs remains unclear.

Unions sometimes are prepared to acquiesce with reductions in employment where older workers get laid off first and get retirement benefits or extended unemployment or disability benefits. While a disproportionate share of workers who are laid-off do not get other jobs the ones who do may not be able to obtain union jobs. Consistent with this, Bertola, Blau and Kahn (2005), in a study of seventeen OECD countries, find that greater unionization lowers the relative employment of older workers.

b) Union workers retire in their late forties and early fifties and quit the labor force. Hence, union density rates for the older age groups decline, simply because of the attrition of the union workers from the workforce - there are simply fewer union employees than there were in the past. This is likely to be an important phenomenon in the public sector especially for some groups such as police and sheriffs who are able to retire after 20 years of service at a relatively young age. Care needs to be taken with this explanation, however, given the evidence presented in the OECD Employment Outlook of 2004 (Table C) that between 1990 and 2003 the labor force participation rate of those aged 55-64 increased in all the major OECD countries except Italy. ${ }^{39}$ This is true for both men and women separately and taken together.

c) Union members lose their jobs and become unemployed. Carruth and Disney (1988) charted the dramatic drop in employment and the rise in unemployment in the UK between 1979 and 1982 and the interesting coincidence of a decline in union membership of 2 million over the same time period. There is reason to believe that many of the union workers who became unemployed in the early eighties became long-term unemployed. In most OECD countries the issue of long-term unemployment has been a serious one and has been 'solved' by moving the long term unemployed to disability. Disability has grown rapidly over time in many countries including the US (Autor and Duggan, 2003) and the UK (Blanchflower and Bell, 2006). According to the OECD Employment Outlook of 2004 despite an unemployment rate of $4.4 \%$ in 2002, Denmark spent 4.63\% of GDP to labor market programs including $2.58 \%$ of GDP for the disabled. This compares with Belgium that had an unemployment rate of $7.3 \%$ and spent 3.52\% of GDP including 2.18\% of GDP for the disabled, 2.42\% in Spain, 2.45\% in Sweden, $0.71 \%$ in the USA and $0.75 \%$ in the UK in 2002/3.

In the US the existence of temporary layoffs in the union sector help explain the absence of union members from the employee counts but this does not help us across countries as this phenomenon does not generally exist in other countries including the UK.

d) Union members quit their jobs and are promoted to managerial jobs in their own organization, or elsewhere, which are non-union. In both the private and the public sector this phenomenon can operate; for example in most police forces in the US promotions to the levels of Sergeant and Lieutenant do not usually involve a change in union status but more likely to a different union. Promotion to Captain, Commander and beyond involves a move from one side of the bargaining table to the other. Chiefs of police and plant managers are generally not union members.

39 Other exceptions are Korea, Mexico and Turkey. Data are unavailable for the ex-Communist countries. 
e) One obvious answer would be that there are simply cohort effects at work here. Table 16 addresses that question for the United States for the period 1983-2002, the longest period available, and pooling together 20 MORG CPS files with just over 3.4 million data points. Due to the size of the data file we only include gender and private sector dummies while in columns 3 and 4 an additional 50 state dummies are included. Eleven age dummies are included in the first column with a maximum probability at age group 55-59. There are no controls for time here. Adding cohort dummies for decade of birth suggests there are cohort effects - the probabilities of being a union member for the cohort born in the 1980s compared to someone (me) born in the 1950s have a two percentage point lower probability of being a union member. There is still evidence of an inverted U-shape but now with a maximum in the age group 35-39 but now the higher ages have significantly negative coefficients. Adding state dummies reduces slightly the size of the coefficients on the cohort dummies.

Figure 3 presents the results of checking for cohort effects in a more detailed way that confirms the findings in Table 16. Using the same CPS data for the United States for the period 19832002 I estimated a union dprobit that included controls for gender, 3 race dummies, a private sector dummy and 19 year dummies along with a separate dummy for each year of age. The coefficients on these are plotted as the higher line. The lower three lines report the results of adding a further 90 year of birth cohort dummies, overall and for men and women separately. The results are consistent with those presented in Table 19; there is still an inverted U-shape in age which is lower and somewhat flatter than without the cohort effects. There is an obvious peak for men and then a decline after the mid 30s whereas for women the function peaks at around thirty and remains more or less flat until age 60. Figure 4 plots the coefficients on the year of birth dummies for men and women combined only and shows a steady decline in the probability of union membership for those born between 1930 and approximately 1965 and then a flat path after that. ${ }^{40}$

There are cohort effects in union membership in the US. Union membership in the US increased from 1935-1950, was fairly flat from 1950-1975 and the declined steadily. One of the reasons that the flow has stabilized since the 1965 birth cohort who were aged twenty five in 1990 is that there are large outflows from union membership as the big cohorts retire. Further, birth cohort size was shrinking from 1960 as the baby boom was ending, so even a steady cohort effect means shrinking numbers. Removing the cohort effects, however, does not remove the inverted U-shape in age although it does flatten it somewhat. Lack of suitable data prevents us from doing a similar exercise in other countries.

f) Union workers are disproportionately employed in older workplaces many of which have are in traditional industries that have been subject to increased competition. When downsizing or plant closings occur union members lose their jobs and are unable to replace them with comparable union jobs. In the General Social Survey both union and non-union workers were asked 'how easy would it be for you to find a job with another employer with approximately the same income and fringe benefits you now have?". Three options were given - very easy, somewhat easy and not easy at all. Pooling the years 1977-2004 to ensure a reasonable sample

\footnotetext{
40 A similar exercise was conducted for the UK using the LFS but with a considerably shorter time run (1992-2004). The picture of the age dummies, with and without cohort dummies, was similar to that reported here but the birth dummies showed a steady downward path.
} 
size, the percent saying 'not easy at all' was $37.4 \%$ in the non-union sector and $56.3 \%$ in the union sector $(\mathrm{n}=8,666)$.

h) Older union workers free-ride more as they get older. They enjoy union benefits but stop paying their union dues. This is likely of particular importance in France where density rates are in single digits but coverage close to complete. Evidence in Bryson (2004b) suggests that this is unlikely to be important in both Britain and New Zealand as free-riding in unionized workplaces appears to be higher amongst the young and lowest among the longest tenured. However, it is higher among managers in both countries than non-managers. It is less of an issue in the US where unionization occurs at the level of the workplace and coverage is little higher than membership.

i) Older and younger workers have less 'need' for unions than prime age workers. We found evidence that the support for unions among union members declines with age for European countries in Table 4 and in Bryson and Freeman (2006) for the UK and the USA and in Lipset and Meltz (2004) for the US and Canada.

j) The most productive union members quit because the seniority/wage compression rule reduces their potential earnings. Rising wage inequality implies the most productive union members are the ones that have the most to gain from quitting their union jobs and moving to non-union jobs in the right hand tail of the wage distribution. Another possibility is that such able union workers set up in business themselves.

k) More highly unionized industries may have a higher proportion of older workers because the benefits brought by unions reduce turnover. Moreover, many of the more highly unionized industries are old and declining and have relatively few entrants. Hence the direction of causation may run from unionization to age rather than from age to unionization (Bain and Price, 1983a, pp. 22-23) and, as Richardson and Catlin point out, "may show more about the kind of industry that employs older workers than about the propensity of old workers to join unions" (1979, pp. 378-379).

l) One important benefit for union workers is overtime working. As Richardson and Catlin have suggested, this will usually be less important for older workers who typically wish to work less overtime than do workers with family responsibilities. Hence older workers might tend to let their membership lapse (1979, p. 378).

It is unclear which of these factors is the primary influence and why the probability of union membership follows an inverse U-shape in age, with broadly similar maxima, across this diverse group of countries - Australia; Austria; Bangladesh; Belgium; Bulgaria; Canada; Chile; Czech Republic; Denmark; Germany; Estonia; Finland; France; Greece; Hungary; Ireland; Israel; Japan; Luxembourg; Mexico; Netherlands; New Zealand; Norway; Poland; Portugal; Russia; Slovak Republic; Slovenia; Spain; Sweden; Switzerland; the UK and the USA. 
Table 1. Union density in OECD countries 1970-2000

\begin{tabular}{|c|c|c|c|c|c|c|c|c|c|c|c|}
\hline & USA & Canada & Australia & New Zealand & Japan & Korea (1) & Korea (2) & Germany & France & Italy & UK \\
\hline 1970 & 23.5 & 31.6 & 50.2 & 55.2 & 35.1 & 12.6 & & 32.0 & 21.7 & 37.0 & 44.8 \\
\hline 1980 & 19.5 & 34.7 & 49.5 & 69.1 & 31.1 & 14.7 & 21.0 & 34.9 & 18.3 & 49.6 & 50.7 \\
\hline 1990 & 15.5 & 32.9 & 40.5 & 51.0 & 25.4 & 17.6 & 18.4 & 31.2 & 10.1 & 38.8 & 39.3 \\
\hline 1991 & 15.5 & & & 44.4 & 24.8 & 16.1 & 17.2 & 36.0 & 9.9 & 38.7 & 38.5 \\
\hline 1992 & 15.1 & 33.1 & 39.6 & 37.1 & 24.5 & 15.1 & 16.4 & 33.9 & 9.9 & 38.9 & 37.2 \\
\hline 1993 & 15.1 & 32.8 & 37.6 & 34.5 & 24.3 & 14.5 & 15.6 & 31.8 & 9.6 & 39.2 & 36.1 \\
\hline 1994 & 14.9 & & 35.0 & 30.2 & 24.3 & 13.4 & 14.5 & 30.4 & 9.2 & 38.7 & 34.2 \\
\hline 1995 & 14.3 & & 32.7 & 27.6 & 24.0 & 12.9 & 13.8 & 29.2 & 9.0 & 38.1 & 32.6 \\
\hline 1996 & 14.0 & & 31.1 & 24.9 & 23.4 & 12.2 & 13.3 & 27.8 & 8.3 & 37.4 & 31.7 \\
\hline 1997 & 13.6 & 28.8 & 30.3 & 23.6 & 22.8 & 11.9 & 12.2 & 27.0 & 8.2 & 36.2 & 30.6 \\
\hline 1998 & 13.4 & 28.5 & 28.1 & 22.3 & 22.5 & 12.1 & 12.6 & 25.9 & 8.0 & 35.7 & 30.1 \\
\hline 1999 & 13.4 & 27.9 & 25.7 & 21.9 & 22.2 & 11.1 & 11.9 & 25.6 & 8.1 & 36.1 & 29.8 \\
\hline 2000 & 12.8 & 28.1 & 24.7 & 22.7 & 21.5 & 11.1 & 12.0 & 25.0 & 8.2 & 34.9 & 29.7 \\
\hline 2001 & 12.8 & 28.2 & 24.5 & 22.6 & 20.9 & 11.2 & 12.0 & 23.5 & 8.1 & 34.8 & 29.3 \\
\hline 2002 & 12.6 & 28.2 & 23.1 & 22.1 & 20.3 & 11.1 & 11.6 & 23.2 & 8.3 & 34.0 & 29.2 \\
\hline 2003 & 12.4 & 28.4 & 22.9 & - & 19.7 & 11.2 & & 22.6 & 8.3 & 33.7 & 29.3 \\
\hline 1970 & Finland & $\begin{array}{c}\text { Sweden } \\
677\end{array}$ & Norway & Denmark & Netherlands & Belgium & Spain & Switzerland & Austria & Ireland & Iceland \\
\hline 1980 & 69.4 & 78.0 & 58.3 & 78.6 & 34.8 & 54.1 & 12.9 & 31.1 & $\begin{array}{l}02.8 \\
56.7\end{array}$ & $\begin{array}{l}53.2 \\
57.1\end{array}$ & \\
\hline 1990 & 72.5 & 80.8 & 58.5 & 75.3 & 24.3 & 53.9 & 12.5 & 24.3 & 46.9 & 51.1 & \\
\hline 1991 & 75.4 & 80.6 & 58.1 & 75.8 & 24.1 & 54.3 & 14.7 & 22.7 & 45.5 & 50.2 & 87.9 \\
\hline 1992 & 78.4 & 83.3 & 58.1 & 75.8 & 25.2 & 54.3 & 16.5 & 23.0 & 44.3 & 49.8 & 87.5 \\
\hline 1993 & 80.7 & 83.9 & 58.0 & 77.3 & 25.9 & 55.0 & 18.0 & 22.9 & 43.2 & 47.7 & 86.5 \\
\hline 1994 & 80.3 & 83.8 & 57.8 & 77.5 & 25.6 & 54.7 & 17.6 & 23.3 & 41.4 & 46.2 & 87.4 \\
\hline 1995 & 80.4 & 83.1 & 57.3 & 77.0 & 25.7 & 55.7 & 16.3 & 22.8 & 41.1 & 45.8 & 87.7 \\
\hline 1996 & 80.4 & 82.7 & 56.3 & 77.1 & 25.1 & 55.9 & 16.1 & 22.9 & 40.1 & 45.5 & 87.2 \\
\hline 1997 & 79.5 & 82.2 & 55.5 & 75.3 & 25.1 & 56.0 & 15.7 & 22.6 & 38.9 & 43.5 & 87.8 \\
\hline 1998 & 78.0 & 81.3 & 55.5 & 75.6 & 24.5 & 55.4 & 16.4 & 21.7 & 38.4 & 41.5 & 88.1 \\
\hline 1999 & 76.3 & 80.6 & 54.5 & 74.1 & 24.6 & 55.1 & 16.2 & 21.0 & 37.4 & & 87.4 \\
\hline 2000 & 75.0 & 79.1 & 53.7 & 73.3 & 23.1 & 55.6 & 16.1 & 19.4 & 36.5 & & 89.4 \\
\hline 2001 & 74.5 & 78.0 & 52.8 & 72.5 & 22.5 & & 16.1 & 17.8 & 35.7 & 36.6 & 88.1 \\
\hline 2002 & 74.8 & 78.0 & 53.0 & & 22.4 & 55.4 & 16.2 & & 35.4 & 36.3 & 92.5 \\
\hline 2003 & 74.1 & 78.0 & 53.3 & 70.4 & 22.3 & & 16.3 & & & 35.3 & \\
\hline
\end{tabular}

Source: Visser (2006) except Korea (2) and Iceland from ILO (2005) 
Table 2. Unionization Rates in Latin America, 1976-95 (Percent)

$\begin{array}{lrccc}\text { Country } & 1976-80 & 1981-85 & 1986-90 & 1991-95 \\ \text { Argentina } & & 28.2 & 26.5 & 21.5 \\ \text { Bahamas } & 25.0 & 25.0 & 25.0 & \\ \text { Bolivia } & 32.0 & 28.8 & 25.2 & 16.4 \\ \text { Brazil } & 19.6 & 34.8 & 38.1 & 24.8 \\ \text { Chile } & 9.1 & 9.5 & 13.1 & \\ \text { Colombia } & & 17.7 & 12.1 & \\ \text { Costa Rica } & & 14.3 & 14.9 & 15.0 \\ \text { Dominican Republic } & & 12.2 & 15.3 & 13.4 \\ \text { Ecuador } & & 15.0 & 14.3 & 13.5 \\ \text { El Salvador } & & 8.0 & 14.1 & 15.0 \\ \text { Guatemala } & & 8.1 & 4.4 & \\ \text { Honduras } & & 20.0 & 20.0 & \\ \text { Jamaica } & 28.3 & 22.2 & 20.3 & 16.3 \\ \text { Mexico } & 19.1 & 27.3 & 35.3 & 22.4 \\ \text { Nicaragua } & 3.7 & 32.0 & 32.0 & 23.4 \\ \text { Panama } & 12.5 & 15.0 & 17.0 & 14.2 \\ \text { Paraguay } & 5.0 & 2.8 & & \\ \text { Peru } & 25.0 & 40.0 & 13.0 & 12.9 \\ \text { Trinidad and Tobago } & 27.2 & 31.0 & 25.4 & 22.0 \\ \text { Uruguay } & & 19.3 & 16.3 & \\ \text { Venezuela } & & 18.0 & & \end{array}$

Source: Lora and Pagés-Serra (2003) 
Table 3. Union membership ('000s)

\begin{tabular}{|c|c|c|c|c|}
\hline & 1980 & 1990 & 2003 & Empt change 94-04 \\
\hline Australia & 2,568 & 2,660 & 1,867 & $+21.4 \%$ \\
\hline Austria & 1,444 & 1,375 & 1,151 & $0.6 \%$ \\
\hline Belgium & 1,651 & 1,646 & 1,850 & $12.3 \%$ \\
\hline Canada & 3,543 & 3,898 & 4,037 & $22.3 \%$ \\
\hline Denmark & 1,605 & 1,756 & 1,711 & $-3.7 \%$ \\
\hline Finland & 1,332 & 1,527 & 1,495 & $7.2 \%$ \\
\hline France & 3,282 & 1,968 & 1,830 & $15.2 \%$ \\
\hline Germany & 8,154 & 8,014 & 7,120 & $11.6 \%$ \\
\hline Ireland & 491 & 442 & 516 & $50.8 \%$ \\
\hline Italy & 7,189 & 5,872 & 5,328 & $10.9 \%$ \\
\hline Japan & 12,369 & 12,265 & 10,531 & $-1.9 \%$ \\
\hline Korea & 948 & 1,932 & 1,606 & $13.6 \%$ \\
\hline Netherlands & 1,517 & 1,348 & 1,575 & $20.1 \%$ \\
\hline New Zealand & 714 & 603 & 335 & $24.3 \%$ \\
\hline Norway & 938 & 1,034 & 1,109 & $12.7 \%$ \\
\hline Spain & 1,030 & 1,193 & 2,197 & $46.9 \%$ \\
\hline Sweden & 3,039 & 3,260 & 2,984 & $7.2 \%$ \\
\hline Switzerland & 853 & 820 & 643 & $5.8 \%$ \\
\hline UK & 11,652 & 8,952 & 6,524 & $10.3 \%$ \\
\hline USA & 17,717 & 16,740 & 15,776 & $13.2 \%$ \\
\hline India & 3,727 & 7,019 & 6,407 & $3.2 \%$ \\
\hline Philippines & 1,921 & 3,055 & 3,917 & $27.5 \%$ \\
\hline Malaysia & 579 & 659 & 789 & $\mathrm{n} / \mathrm{a}$ \\
\hline Pakistan & 347 & 360 & 276 & $\mathrm{n} / \mathrm{a}$ \\
\hline Singapore & 244 & 212 & 417 & $2.2 \%$ \\
\hline Sri Lanka & 1,668 & 905 & 641 & $29.9 \%$ \\
\hline Syria & 313 & 523 & 595 & $1.1 \%$ \\
\hline
\end{tabular}

Source: Visser (2005) for OECD and ILO (2005) for non-OECD and OECD in Figures, 2005 
Table 4. 'Need' for trade unions - ordered logits.

\begin{tabular}{|c|c|c|c|c|c|}
\hline & All & Non-workers & Workers & Union workers & Non-union workers \\
\hline Age & $-.0048(8.34)$ & $.0101(2.78)$ & $-.0328(5.47)$ & $-.0061(3.00)$ & $-.0420(6.23)$ \\
\hline $\mathrm{Age}^{2}$ & & $-.00013(3.69)$ & $.00003(4.25)$ & & .0004 (5.08) \\
\hline Male & $-.1233(6.46)$ & $-.0586(2.02)$ & $-.1808(7.06)$ & $-.0274(0.61)$ & $-.2538(8.04)$ \\
\hline Schooling (yrs) & -.0527 (19.64) & -.0385 (9.41) & -.0656 (17.99) & $-.0718(11.05)$ & $-.0592(13.36)$ \\
\hline Belgium & $-.2061(3.33)$ & -.1855 (1.95) & $-.2273(2.77)$ & $-.2756(1.97)$ & $-.2145(2.11)$ \\
\hline Switzerland & $-.0092(0.16)$ & $-.0573(0.59)$ & $.0163(0.22)$ & $-.0484(0.30)$ & $.0674(0.77)$ \\
\hline Czech Republic & .2496 (3.59) & .4592 (4.43) & $.0836(0.89)$ & $.3148(1.55)$ & $.0586(0.55)$ \\
\hline Germany & -.3162 (5.79) & $-.3371(4.06)$ & $-.2755(3.78)$ & -.1752 (1.19) & $-.2836(3.35)$ \\
\hline Denmark & -.3957 (5.97) & $-.1580(1.44)$ & $-.5321(6.35)$ & $-.5862(4.82)$ & $-.5926(3.79)$ \\
\hline Spain & .2476 (3.77) & .0607 (0.64) & .5312 (5.73) & .6355 (2.82) & $.5411(5.22)$ \\
\hline Finland & $.4372(7.12)$ & $.7190(7.70)$ & .2282 (2.79) & .3305 (2.69) & $-.0826(0.66)$ \\
\hline France & .7125 (10.60) & .7212 (7.26) & $.7423(8.07)$ & $.9815(4.16)$ & .7418 (7.23) \\
\hline Great Britain & $-.3611(6.13)$ & $-.3321(3.67)$ & $-.3840(4.93)$ & $-.2090(1.43)$ & $-.4254(4.62)$ \\
\hline Greece & .9639 (16.65) & .9427 (11.15) & $1.0542(12.94)$ & .6552 (3.95) & $1.1748(12.47)$ \\
\hline Hungary & 7905 (12.29) & .7557 (8.12) & $.8774(9.68)$ & .5725 (2.84) & .9607 (9.36) \\
\hline Ireland & .1252 (2.09) & $.2774(3.00)$ & $.0064(0.08)$ & $-.0536(0.38)$ & $.0290(0.30)$ \\
\hline Israel & .7250 (12.33) & .6437 (7.16) & $.8098(10.36)$ & .3203 (2.17) & $.9974(10.80)$ \\
\hline Italy & .1539 (2.17) & $.0880(0.83)$ & .2395 (2.48) & $.0121(0.06)$ & $.3313(2.94)$ \\
\hline Luxembourg & .2267 (3.39) & $.2680(2.77)$ & .2019 (2.15) & $.0233(0.15)$ & .2977 (2.54) \\
\hline Netherlands & $-.1500(2.65)$ & $-.1500(1.68)$ & $-.1385(1.88)$ & $-.2818(2.06)$ & $-.0731(0.83)$ \\
\hline Norway & $-.1278(2.19)$ & $-.0453(0.46)$ & $-.1650(2.25)$ & $-.2264(1.90)$ & $-.1290(1.32)$ \\
\hline Poland & .3438 (5.79) & .3495 (4.04) & .3909 (4.67) & .0867 (0.47) & $.4710(4.95)$ \\
\hline Portugal & 1975 (2.99) & $.0742(0.75)$ & .3344 (3.77) & $-.1178(0.56)$ & $.4438(4.44)$ \\
\hline Sweden & $-.2108(3.53)$ & $.0617(0.64)$ & $-.3635(4.74)$ & $-.3656(3.12)$ & $-.5208(4.39)$ \\
\hline Slovenia & $.5029(7.71)$ & $.5125(5.36)$ & .5144 (5.69) & $.2625(1.80)$ & .7037 (6.02) \\
\hline Self-employed & $-.5201(14.89)$ & & $-.5051(14.02)$ & $-.8009(9.14)$ & $-.4153(10.45)$ \\
\hline Not working & .1164 (5.09) & & & & \\
\hline Union member & $.7771(29.74)$ & .7055 (13.65) & $.8524(27.52)$ & & \\
\hline Cut1 & -4.5730 & -4.1629 & -4.9850 & -5.9187 & -5.4150 \\
\hline Cut2 & -2.8155 & -2.4750 & -3.1967 & -4.0294 & -3.6214 \\
\hline Cut3 & -1.7907 & -1.3798 & -2.2332 & -3.0316 & -2.6339 \\
\hline Cut4 & .3669 & .7997 & -.13681 & -.7564 & -.5245 \\
\hline $\mathrm{N}$ & 39,824 & 17,966 & 21,955 & 7,573 & 14,285 \\
\hline Pseudo $\mathrm{R}^{2}$ & 0.0329 & .0203 & .0279 & .0257 & .0378 \\
\hline
\end{tabular}

Notes: excluded categories employee and Austria. Source: European Social Survey, 2002/3. T-statistics in parentheses 
Table 5. Union membership rates by characteristics, 2004/5

\begin{tabular}{|c|c|c|c|}
\hline & UK (2004) & USA (2005) & Canada (2005) \\
\hline All & 28.8 & 12.5 & 29.8 \\
\hline Males & 28.5 & 13.8 & 29.8 \\
\hline Females & 29.1 & 11.1 & 29.8 \\
\hline White & 29.0 & 12.2 & \\
\hline Asian & 23.5 & 11.4 & \\
\hline Black & 32.5 & 15.1 & \\
\hline Hispanic & & 10.1 & \\
\hline Degree or equivalent & 37.7 & 14.8 & 33.4 \\
\hline A-level or equivalent & 26.4 & 14.3 & 26.7 \\
\hline No qualifications & 21.1 & 7.7 & 28.1 \\
\hline Age 16-19 & 4.3 & 2.9 & 9.7 \\
\hline Age $20-24$ & 13.1 & 5.4 & 14.6 \\
\hline Age 25-29 & 22.4 & 9.4 & 24.4 \\
\hline Age $30-34$ & 27.1 & 11.7 & 28.8 \\
\hline Age 35-39 & 30.9 & 13.3 & 30.0 \\
\hline Age 40-44 & 34.5 & 14.1 & 33.5 \\
\hline Age 45-49 & 38.9 & 16.1 & 38.6 \\
\hline Age $50-54$ & 39.7 & 18.2 & 42.2 \\
\hline Age 55-59 & 36.0 & 17.9 & 40.0 \\
\hline Age 60-64 & 27.8 & 15.1 & 32.7 \\
\hline Age 65-69 & 9.6 & 7.9 & 16.2 \\
\hline Age $>=70$ & 5.9 & 6.9 & 12.1 \\
\hline Private & 17.2 & 9.0 & 17.4 \\
\hline Public & 58.8 & 37.2 & 71.4 \\
\hline Manufacturing & 24.6 & 12.9 & 30.0 \\
\hline Construction & 16.7 & 14.7 & 30.9 \\
\hline Managers & 18.6 & 13.1 & 8.1 \\
\hline Professional occupations & 48.6 & 18.2 & 14.6 \\
\hline Skilled trades & 26.0 & 19.4 & 38.0 \\
\hline
\end{tabular}

Source: UK - Grainger and Holt (2005). USA - Union members in 2005, BLS, UDDL 06-99 www.bls.gov/news.release/pdf/union2. For Canada Labour Force Survey December 2005 and for the rates by age UK Labour Force Survey Fall 2004 and for the US MORG 2004 all weighted (own calculations). 
Table 6. Union density in the private and public sectors, Great Britain, Canada and USA (\%)

$\begin{array}{lccccc}\text { Great Britain } & \text { Private } & \text { Public } & \text { Canada } & \text { Private } & \text { Public } \\ 1948 & & 70.7 & 1960 & 30.0 & 11.8 \\ 1968 & & 66.1 & 1970 & 29.3 & 37.6 \\ 1973 & & 73.0 & 1974 & 28.3 & 48.7 \\ 1979 & & 82.4 & 1980 & 26.0 & 56.0 \\ 1993 & 24.0 & 64.4 & 1984 & 20.7 & 63.1 \\ 1994 & 22.8 & 63.6 & 1990 & 20.6 & 64.3 \\ 1995 & 21.5 & 61.4 & 1997 & 22.1 & 72.6 \\ 1996 & 20.7 & 60.9 & 2001 & 18.1 & 71.0 \\ 1997 & 19.8 & 60.8 & 2005 & 17.4 & 71.1 \\ 1998 & 19.5 & 61.0 & & & \\ 1999 & 19.3 & 59.9 & & & \\ 2000 & 18.7 & 60.0 & & & \\ 2001 & 18.5 & 59.0 & & & \\ 2002 & 18.1 & 59.3 & & & \\ 2003 & 18.1 & 58.8 & & & \\ 2004 & 17.1 & 58.4 & & & \\ 2004 \text { UK } & 17.2 & 58.8 & & & \\ & & & & & \\ \text { USA } & & & 1991 & 11.9 & 36.5 \\ 1960 & 31.9 & 10.8 & 1992 & 11.4 & 36.6 \\ 1970 & 29.1 & 32.0 & 1993 & 11.1 & 37.7 \\ 1977 & 21.7 & 32.8 & 1994 & 10.8 & 38.7 \\ 1978 & 20.7 & 33.3 & 1995 & 10.3 & 37.7 \\ 1979 & 21.2 & 37.0 & 1996 & 10.0 & 37.6 \\ 1980 & 20.1 & 35.9 & 1997 & 9.7 & 37.2 \\ 1981 & 18.7 & 34.3 & 1998 & 9.5 & 37.5 \\ 1983 & 16.5 & 36.7 & 1999 & 9.4 & 37.3 \\ 1984 & 15.3 & 35.7 & 2000 & 9.0 & 37.5 \\ 1985 & 14.3 & 35.7 & 2001 & 9.0 & 37.4 \\ 1986 & 13.8 & 35.9 & 2002 & 8.6 & 37.8 \\ 1987 & 12.7 & 35.9 & 8.2 & 37.2 \\ 1988 & 12.3 & 36.6 & 2004 & 7.9 & 36.4 \\ 1989 & 12.3 & 36.7 & & & \\ 1990 & 11.9 & 36.5 & & & 36.5 \\ & & & & & \end{array}$

Source: GB/UK=Grainger and Holt, Department of Trade and Industry, April 2005. www.dti.gov.uk/er/emar/tradeunion_membership2004.pdf. USA=www.unionstats.com Canada=Lipset and Meltz (2004) and LFS December 2005. Data for the UK, 1948-1979 from Bain and Price (1983b) Table 5 
Table 7. Dprobit union membership, UK: 1993-2004 and 1983

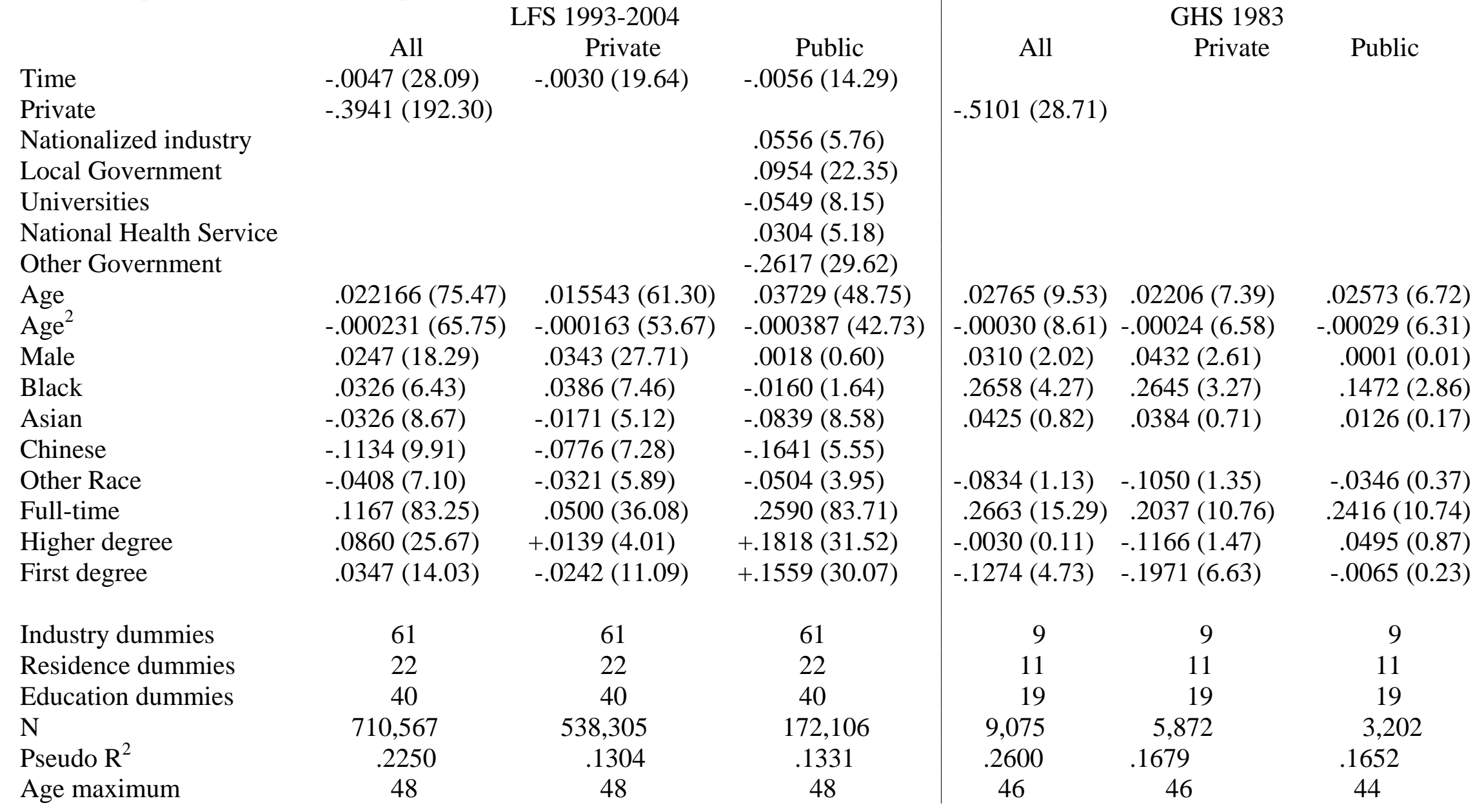

Notes: excluded categories white, no qualifications and central govt. T-statistics in parentheses Source: Labour Force Surveys, 1993-2004 and 1983 General Household Survey 
Table 8. Dprobit Union Membership in the USA, 1984-1991

$\begin{array}{lccc} & \text { All } & \text { Private } & \text { Public } \\ \text { Time } & -.0036(37.62) & -.0040(44.10) & -.0000(0.12) \\ \text { Private } & -.1894(155.61) & & \\ \text { State Government } & & & .1188(33.32) \\ \text { Local Government } & & .2103(64.57) \\ \text { Age } & .0132594(101.73) & .009822(83.73) & .02883(52.06) \\ \text { Age } & -.000142(90.56) & -.000103(72.66) & -.000319(49.47) \\ \text { Male } & .0421(74.47) & .0435(81.35) & .0212(10.17) \\ \text { Years schooling } & -.0083(79.10) & -.0105(105.34) & .0061(15.46) \\ \text { Black } & .0729(71.26) & .0694(68.10) & .0920(28.10) \\ \text { Other race } & -.0166(11.60) & -.0004(0.26) & -.0832(15.45) \\ \text { Hispanic } & .0108(8.92) & .0020(1.88) & .0396(7.56) \\ \text { Fulltime } & .0590(82.39) & .0237(34.12) & .2572(96.10) \\ & & & \\ \text { Industry dummies } & 45 & 45 & 45 \\ \text { State dummies } & 51 & 51 & 51 \\ & & & \\ \mathrm{~N} & 1,600,112 & 1,315,835 & 284,243 \\ \text { Pseudo R }{ }^{2} & .2278 & .2136 & .2072 \\ \text { Age maximum } & 47 & 48 & 45\end{array}$

Source: MORG files of the CPS 1984-1991. T-statistics in parentheses 
Table 9. Dprobit Union Membership in the USA, 1992-2002

$\begin{array}{lccc} & \text { All } & \text { Private } & \text { Public } \\ \text { Time } & -.0018(26.98) & -.0018(30.40) & -.0007(2.56) \\ \text { Private } & -.1926(183.27) & & \\ \text { State Government } & & & .0960(28.30) \\ \text { Local Government } & & & .1759(55.38) \\ \text { Age } & .010518(96.97) & .00697(75.44) & .032726(61.98) \\ \text { Age } & -.000108(84.45) & -.000068(62.15) & -.0003564(58.90) \\ \text { Male } & .0329(69.73) & .0318(74.60) & .0359(17.81) \\ \text { Black } & .0508(61.21) & .0472(60.12) & .0613(19.68) \\ \text { American Indian } & -.0347(18.14) & -.0007(0.34) & -.1616(22.15) \\ \text { Asian/Pacific Islander } & -.0111(9.39) & .0012(1.08) & -.0721(12.66) \\ \text { Hispanic } & .0137(15.10) & .0121(15.50) & .0252(5.76) \\ \text { Fulltime } & .0152(29.81) & .0023(4.78) & .0957(44.38) \\ & & & \\ \text { First degree } & .0238(3.75) & -.0120(2.77) & .4284(7.46) \\ \text { Master's degree } & .0411(8.16) & -.0206(5.12) & .2197(3.66) \\ \text { Professional degree } & -.0272(4.91) & -.0251(6.04) & .2197(3.66) \\ \text { Higher degree } & -.0411(8.16) & -.0352(9.37) & .2294(3.82) \\ \text { Industry dummies } & & & \\ \text { State dummies } & 45 & 45 & 45 \\ \text { Schooling dummies } & 51 & 51 & 51 \\ & 16 & 16 & 16 \\ \mathrm{~N} & 1,811,934 & 1,501,651 & 310,269 \\ \text { Pseudo R }{ }^{2} & .2373 & .1878 & .1938 \\ \text { Age maximum } & 49 & 51 & 46\end{array}$

Source: ORG files of the CPS, 1992-2002

Notes: Excluded category Federal Government, Maine, $<1^{\text {st }}$ grade education and white. T-statistics in parentheses 
Table 10. Union density equations for Canada, 1997-2005.

$\begin{array}{lccc} & \text { All } & \text { Private } & \text { Public } \\ \text { Age 20-24 } & .0520(15.56) & .0370(14.54) & .1606(20.23) \\ \text { Age 25-29 } & .1508(43.62) & .0818(30.11) & .2670(43.15) \\ \text { Age 30-34 } & .1933(56.17) & .1086(39.49) & .2935(49.52) \\ \text { Age 35-39 } & .2179(64.53) & .1327(48.57) & .3092(51.09) \\ \text { Age 40-44 } & .2394(71.52) & .1559(56.60) & .3234(52.02) \\ \text { Age 45-49 } & .2615(76.90) & .1845(63.90) & .3274(52.31) \\ \text { Age 50-54 } & .2693(76.79) & .1957(64.03) & .3182(52.30) \\ \text { Age 55-59 } & .2472(65.28) & .1823(54.69) & .2798(47.77) \\ \text { Age 60-64 } & .2079(44.82) & .1466(35.93) & .2527(40.07) \\ \text { Age 65-69 } & .0123(1.47) & .0111(1.56) & .1650(12.83) \\ \text { Age >=70 } & -.0421(3.21) & -.0065(0.58) & .1026(4.76) \\ & & & \\ \text { Time } & -.00008(0.38) & -.0010(5.98) & .0028(7.48) \\ \text { Male } & .0577(49.00) & .0675(66.94) & -.0214(10.12) \\ \text { Some secondary } & .0281(8.76) & .0144(5.97) & .0855(10.43) \\ \text { Grades 11-13 } & .0365(11.81) & .0195(8.32) & .1175(15.49) \\ \text { Some post secondary } & .0044(1.31) & .0054(2.08) & .0739(9.05) \\ \text { Post secondary } & .0322(10.84) & .0103(4.58) & .1456(18.64) \\ \text { Bachelor's degree } & -.0301(9.42) & -.0654(27.48) & .1146(14.88) \\ \text { Postgraduate degree } & -.0978(29.26) & -.0848(28.47) & .0224(2.72) \\ \text { December } & .0024(2.29) & .0023(2.57) & -.0022(1.15) \\ \text { Private } & -.4657(223.92) & & \\ \text { Industry dummies } & & & \\ \text { Province dummies } & 18 & 18 & \\ & 9 & 9 & \\ \text { N } & & & .0685 \\ \text { Pseudo R } & & & \end{array}$

Source: Canadian Labour Force Surveys, June 1997-December 2005. T-statistics in parentheses 
Table 11. European Union density equations

\begin{tabular}{lcccr} 
& Male & Age maximum & 2001 dummy & \multicolumn{1}{c}{$\mathrm{N}$} \\
All & .0523 & 47 & -.0664 & 247,883 \\
Belgium & .0704 & 38 & -.0569 & 19,025 \\
Denmark & .0436 & 46 & -.1799 & 18,782 \\
East Germany & .0266 & 44 & $\mathrm{n} / \mathrm{a}$ & 14,531 \\
France & .0228 & 53 & -.0223 & 19,081 \\
Great Britain & .0753 & 47 & -.0706 & 19,396 \\
Greece & .0480 & 46 & -.0249 & 18,976 \\
Ireland & .0305 & 44 & $-.0167^{*}$ & 19,019 \\
Italy & .0441 & 51 & -.0668 & 19,643 \\
Luxembourg & .1432 & 47 & -.0482 & 7,870 \\
Netherlands & .1024 & 53 & -.0457 & 19,023 \\
Northern Ireland & .0538 & 47 & -.0476 & 5,367 \\
Norway & .0386 & 54 & $\mathrm{n} / \mathrm{a}$ & 7,570 \\
Portugal & .0231 & 50 & $-.0128^{*}$ & 18,102 \\
Spain & .0227 & 45 & -.0139 & 18,881 \\
West Germany & .1096 & 43 & -.0496 & 19,636 \\
& & & & \\
Employees & .1058 & 45 & $-.0666^{*}$ & 64,727 \\
Belgium & .0572 & 37 & $.0802^{*}$ & 5496 \\
Denmark & .0335 & 43 & $.0154^{*}$ & 6428 \\
East Germany & $.0152^{*}$ & 45 & $\mathrm{n} / \mathrm{a}$ & 4690 \\
France & .0556 & 51 & $-.0230^{*}$ & 5335 \\
Great Britain & .1891 & 45 & -.0875 & 5852 \\
Greece & .1045 & 45 & -.1657 & 3102 \\
Ireland & .1142 & 42 & .1142 & 4417 \\
Italy & .0731 & 46 & -.1501 & 4225 \\
Luxembourg & .1928 & 47 & $.1321^{*}$ & 1640 \\
Netherlands & .2081 & 47 & $.0458^{*}$ & 4511 \\
Northern Ireland & .1372 & 41 & $-.0944^{*}$ & 1458 \\
Norway & $.0422 *$ & 52 & $\mathrm{n} / \mathrm{a}$ & 2166 \\
Portugal & .0465 & 48 & $.0011^{*}$ & 5007 \\
Spain & .0500 & 47 & $-.0453^{*}$ & 4203 \\
West Germany & .1906 & 45 & $.0268^{*}$ & 5411 \\
& & & & \\
& & 45 & &
\end{tabular}

Notes: *=insignificantly different from zero $(t<1.90)$. Equations include 9 schooling dummies and 22 labor market status variables.

Source: Eurobarometer Trend File, 1988-1994 \& 2001 using the following surveys - 1988 (30); 1989 (31, 31a, 32a); 1990 (33, 34.0, 34.1); 1991 (35.0, 35.1, 36); 1992 (37.0, 37.1, 38.0); 1993 (39.0, 39.1, 40); 1994 (41.0, 41.1) and 2001 (56.1) with Eurobarometer numbers in parentheses 
Table 12. Union density equations in Europe, 2002-2004

\begin{tabular}{|c|c|c|c|}
\hline & Workers & Private & Public \\
\hline Age & .03407 (21.07) & .0295 (17.31) & .0433 (12.12) \\
\hline Age $^{2}$ & $-.00034(17.86)$ & $-.0003(14.68)$ & $-.0004(10.37)$ \\
\hline Male & .0541 (8.98) & $.0692(10.61)$ & .0107 (0.88) \\
\hline Years schooling & $.0076(5.43)$ & $-.0030(3.14)$ & $.0089(5.66)$ \\
\hline Year 2002 & -.0539 (8.57) & $-.0571(8.31)$ & $-.0349(2.76)$ \\
\hline Belgium & $.1493(8.85)$ & $.2234(11.15)$ & $-.0181(0.60)$ \\
\hline Czech Republic & -.1752 (11.28) & -.1366 (8.39) & $-.3015(8.34)$ \\
\hline Denmark & .5359 (31.03) & .5457 (25.77) & $.4514(16.76)$ \\
\hline Estonia & -.2245 (11.69) & $-.1945(9.72)$ & $-.2822(6.49)$ \\
\hline Finland & $-.1802(10.68)$ & $-.1465(8.30)$ & $-.2755(7.16)$ \\
\hline France & $-.2362(11.29)$ & $-.1843(7.72)$ & $-.3404(8.21)$ \\
\hline Germany & $-.1392(9.82)$ & $-.0982(6.26)$ & $-.2443(8.54)$ \\
\hline Great Britain & $-.0558(3.55)$ & -.1098 (6.32) & .0487 (1.71) \\
\hline Greece & $-.1209(7.42)$ & $-.1076(6.12)$ & -.1319 (3.95) \\
\hline Ireland & .0902 (4.31) & $.0444(1.90)$ & .1772 (4.79) \\
\hline Israel & $-.0761(4.01)$ & $-.1099(4.96)$ & $-.0134(0.41)$ \\
\hline Italy & $-.0807(3.04)$ & $-.0402(1.33)$ & $-.1689(3.32)$ \\
\hline Luxembourg & $.1528(8.47)$ & .1407 (6.87) & .1623 (4.99) \\
\hline Netherlands & $-.0489(2.72)$ & $-.0415(2.05)$ & $-.0587(1.75)$ \\
\hline Norway & $.2681(17.02)$ & $.2146(11.61)$ & $.3246(12.86)$ \\
\hline Poland & $-.1476(8.85)$ & $-.1466(8.40)$ & -.1200 (3.35) \\
\hline Portugal & $-.1469(8.72)$ & $-.1528(8.56)$ & -.0995 (2.88) \\
\hline Slovenia & $.1574(8.36)$ & .1820 (8.61) & .0536 (1.43) \\
\hline Spain & .4126 (25.25) & .3898 (20.11) & .4016 (15.00) \\
\hline Sweden & $.4608(29.16)$ & $.4490(23.57)$ & .4229 (16.79) \\
\hline Switzerland & $-.1492(10.20)$ & $-.1346(8.53)$ & $-.1715(5.73)$ \\
\hline Private sector & $-.0408(1.66)$ & & \\
\hline Private*schooling & $-.0106(6.18)$ & & \\
\hline $\mathrm{N}$ & 33,116 & 23,472 & 9,644 \\
\hline Pseudo $\mathrm{R}^{2}$ & .2182 & .1991 & .2224 \\
\hline Age maximum & 50 & 49 & 54 \\
\hline
\end{tabular}

Source: European Social Survey, 2002 \& 2004. Austria is the excluded category. Public sector is defined based on industry codes working in public administration, education or health. T-statistics in parentheses 
Table 13. Union density equations for twenty two European countries, 2002/3

\begin{tabular}{|c|c|c|c|c|c|}
\hline Age & laximum & Male & Private sector & Schooling & $\begin{array}{l}\text { Schooling* } \\
\text { Private }\end{array}$ \\
\hline Workers $(n=33,116)$ & 49 & + & - & + & - \\
\hline Austria $(n=2,006)$ & $*$ & + & - & - & + \\
\hline Belgium $(n=1,585)$ & 37 & + & $*$ & - & $*$ \\
\hline Czech Republic $(n=1,745)$ & 50 & $*$ & $*$ & $*$ & $*$ \\
\hline Denmark $(n=1,646)$ & 46 & $*$ & + & $*$ & - \\
\hline Estonia $(n=1,002)$ & 45 & $*$ & $*$ & $*$ & $*$ \\
\hline Finland $(n=1,946)$ & 45 & - & $*$ & $*$ & $*$ \\
\hline France $(n=655)$ & $*$ & $*$ & $*$ & + & $*$ \\
\hline Germany $(n=2,470)$ & 48 & + & $*$ & $*$ & - \\
\hline Great Britain $(n=1,828)$ & 53 & $*$ & $*$ & + & - \\
\hline Greece (n=1,530) & 54 & + & - & $*$ & + \\
\hline Ireland (n=847) & 47 & + & + & + & - \\
\hline Israel (n=1,007) & 60 & $*$ & $*$ & + & - \\
\hline Italy $(n=389)$ & $*$ & + & - & $*$ & $*$ \\
\hline Luxembourg $(n=1,293)$ & 53 & + & $*$ & $*$ & $*$ \\
\hline Netherlands $(\mathrm{n}=1,186)$ & $*$ & + & $*$ & $*$ & - \\
\hline Norway $(n=2,295)$ & 55 & $*$ & $*$ & + & - \\
\hline Poland $(n=1,423)$ & 48 & $*$ & $*$ & $*$ & - \\
\hline Portugal $(n=1,422)$ & 56 & + & - & + & $*$ \\
\hline Slovenia $(n=1,117)$ & 50 & - & $*$ & $*$ & $*$ \\
\hline Spain $(n=1,343)$ & $*$ & + & $*$ & $*$ & $*$ \\
\hline Sweden $(n=2,211)$ & 45 & - & $*$ & $*$ & $*$ \\
\hline Switzerland $(n=2,170)$ & 43 & + & $*$ & + & - \\
\hline
\end{tabular}

Notes: age maximum is calculated when both age and age ${ }^{2}$ terms are significant. * = insignificant; += positive and significant -=negative and significant. Calculated from separate country equations. Workers only

Source: European Social Survey, 2002 \& 2004. 
Table 14. Union membership probabilities in 34 countries (workers only)

$\begin{array}{lccc} & \text { All } & \text { Private } & \text { Public } \\ \text { Male } & .0143(3.12) & .0484(9.33) & -.0368(4.79) \\ \text { Age } & .0294(22.83) & .0205(14.39) & .0397(17.85) \\ \text { Age }^{2} & -.00031(20.40) & -.00021(12.63) & -.0004(16.07) \\ \text { Years of education } & .0104(11.05) & -.0017(2.01) & .0111(9.94) \\ \text { Private } & -.0456(2.58) & & \\ \text { Private*education } & -.0130(9.81) & & \\ & & & \\ \mathrm{N} & 48,194 & 27,407 & 20,787 \\ \text { Pseudo R } \mathrm{R}^{2} & .2089 & .1710 & 50 \\ \text { Age maximum } & 47 & 46 & \end{array}$

Notes: Workers only. Equations also include 33 country dummies for Australia (excluded); Germany-West; Germany-East; Great Britain; United States; Austria; Hungary; Ireland; Netherlands; Norway; Sweden; Czech Republic; Slovenia; Poland; Bulgaria; Russia; New Zealand; Canada; Philippines; Israel; Japan; Spain; Latvia; Slovak Republic; France; Cyprus; Portugal; Chile; Denmark; Switzerland; Bangladesh; Brazil; Finland and Mexico

Source: ISSP 2000-2002. T-statistics in parentheses 
Table 15. Union density equations by country, 2000-2002

\begin{tabular}{lccccc|c} 
& Private & Schooling & $\begin{array}{c}\text { Private* } \\
\text { Schooling }\end{array}$ & Male & Age max & Union \\
density \\
Workers (n=48,194) & - & + & - & + & 47 & $28 \%$ \\
OECD (n=28,121) & - & + & - & + & 46 & $32 \%$ \\
Non-OECD (n=20,073) & - & + & - & - & 51 & $21 \%$ \\
Australia (n=1,352) & + & + & - & $*$ & 43 & $20 \%$ \\
Austria (n=692) & $*$ & $*$ & $*$ & + & 44 & $35 \%$ \\
Bangladesh (n=750) & + & - & - & + & 27 & $35 \%$ \\
Brazil (n=769) & $*$ & $*$ & $*$ & $*$ & $*$ & $5 \%$ \\
Bulgaria (n=708) & $*$ & + & $*$ & $*$ & 46 & $16 \%$ \\
Canada (n=1,027) & $*$ & $*$ & - & + & 45 & $26 \%$ \\
Chile (n=1,925) & $*$ & $*$ & $*$ & $*$ & 50 & $12 \%$ \\
Cyprus (n=1,406) & $*$ & + & - & $*$ & $*$ & $32 \%$ \\
Czech Republic (n=1,909) & $*$ & $*$ & - & $*$ & 53 & $20 \%$ \\
Denmark (n=1,824) & - & $*$ & $*$ & + & 46 & $77 \%$ \\
Finland (n=1,956) & $*$ & $*$ & $*$ & - & 45 & $76 \%$ \\
France (n=1,900) & $*$ & $*$ & $*$ & + & 65 & $17 \%$ \\
Germany-East (n=663) & $*$ & $*$ & $*$ & $*$ & 41 & $16 \%$ \\
Germany-West (n=1,406) & + & $*$ & - & + & 43 & $18 \%$ \\
Great Britain (n=2,069) & + & + & - & + & 44 & $22 \%$ \\
Hungary (n=921) & $*$ & $*$ & $*$ & $*$ & 64 & $14 \%$ \\
Ireland (n=1,096) & + & + & - & + & 44 & $38 \%$ \\
Israel (n=1,812) & $*$ & + & - & $*$ & 51 & $27 \%$ \\
Japan (n=1,230) & - & $*$ & + & $*$ & 36 & $28 \%$ \\
Latvia (n=1,493) & - & + & $*$ & $*$ & $*$ & $15 \%$ \\
Mexico (n=1,073) & $*$ & + & $*$ & $*$ & 51 & $13 \%$ \\
Netherlands (n=1,486) & $*$ & $*$ & $*$ & + & $*$ & $30 \%$ \\
New Zealand (n=1,718) & + & + & - & $*$ & 50 & $20 \%$ \\
Norway (n=2,554) & - & - & $*$ & $*$ & 50 & $51 \%$ \\
Philippines (n=1,448) & $*$ & + & - & $*$ & $*$ & $1 \%$ \\
Poland (n=1,003) & $*$ & + & - & $*$ & 45 & $11 \%$ \\
Portugal (n=939) & - & + & $*$ & $*$ & 59 & $15 \%$ \\
Russia (n=2,666) & - & $*$ & $*$ & - & 55 & $34 \%$ \\
Slovak Republic (n=610) & $*$ & + & $*$ & $*$ & 57 & $19 \%$ \\
Slovenia (n=1,507) & - & - & $*$ & - & 44 & $35 \%$ \\
Spain (n=1,803) & $*$ & + & $*$ & + & 45 & $11 \%$ \\
Sweden (n=1,210) & $*$ & $*$ & - & - & 47 & $74 \%$ \\
Switzerland (n=1,699) & - & $*$ & $*$ & + & 46 & $18 \%$ \\
United States (n=1,503) & + & $*$ & - & + & 44 & $13 \%$ \\
& & & & & &
\end{tabular}

Notes: *=insignificantly different from zero $(\mathrm{t}<1.90)$. Estimates obtained from a separate equation for each country. Workers only. Mean years schooling - Australia 12.2; Germany-West 11.1; Germany-East 11.6; Great Britain 12.1; United States 13.6; Austria 10.7; Hungary 11.3; Ireland 13.2; Netherlands 13.2; Norway 13.4; Sweden 12.1; Czech Republic 12.5; Slovenia 11.9; Poland 12.6; Bulgaria 11.7; Russia 12.6; New Zealand 13.3; Canada 13.7; Philippines 9.6; Israel Jews 13.3; Japan 13.2; Spain 11.6; Latvia 14.3; Slovakia 12.2; France 14.3; Cyprus 11.9; Portugal 7.8; Chile 11.5; Denmark 14.7; Switzerland 12.1; Bangladesh 12.0; Finland 12.8; Mexico 9.5; All 12.3. Results for Brazil not reported due to small sample size. Source: ISSP 2000-2002 
Table 16. Union density equations and cohort effects for USA, 1983-2002.

\section{Age 20-24 \\ Age 25-29 \\ Age 30-34 \\ Age 35-39 \\ Age 40-44 \\ Age 45-49 \\ Age 50-54 \\ Age 55-59 \\ Age 60-64 \\ Age 65-69 \\ Age $>=70$ \\ Male \\ Private sector \\ Born 1900-1909 \\ Born 1910-1919 \\ Born 1920-1929 \\ Born 1930-1939 \\ Born 1940-1949 \\ Born 1950-1959 \\ Born 1960-1969 \\ Born 1970-1979 \\ Born 1980-1989}

State dummies (50)

$\mathrm{N}$

Pseudo $\mathrm{R}^{2}$

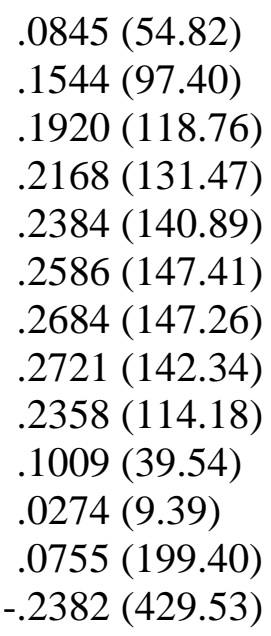

3,429,407

.1011

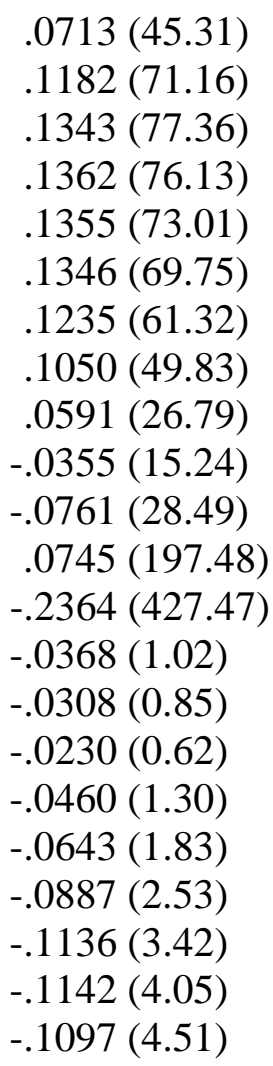

No

3,429,407

.1044

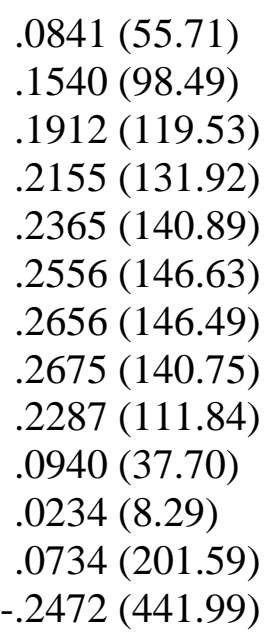

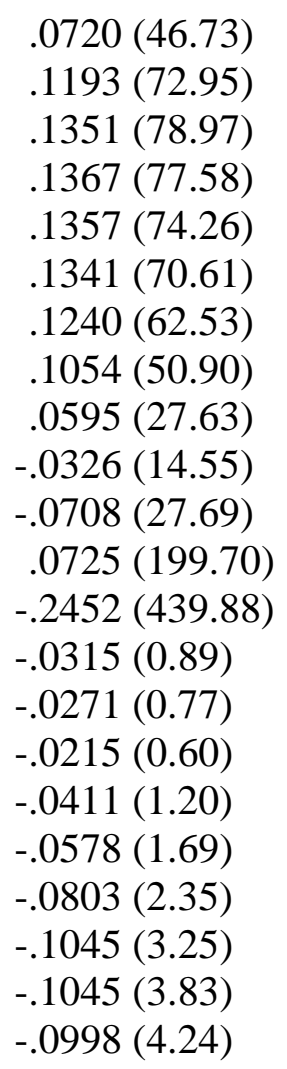

Yes

$3,429,407$ .1480 


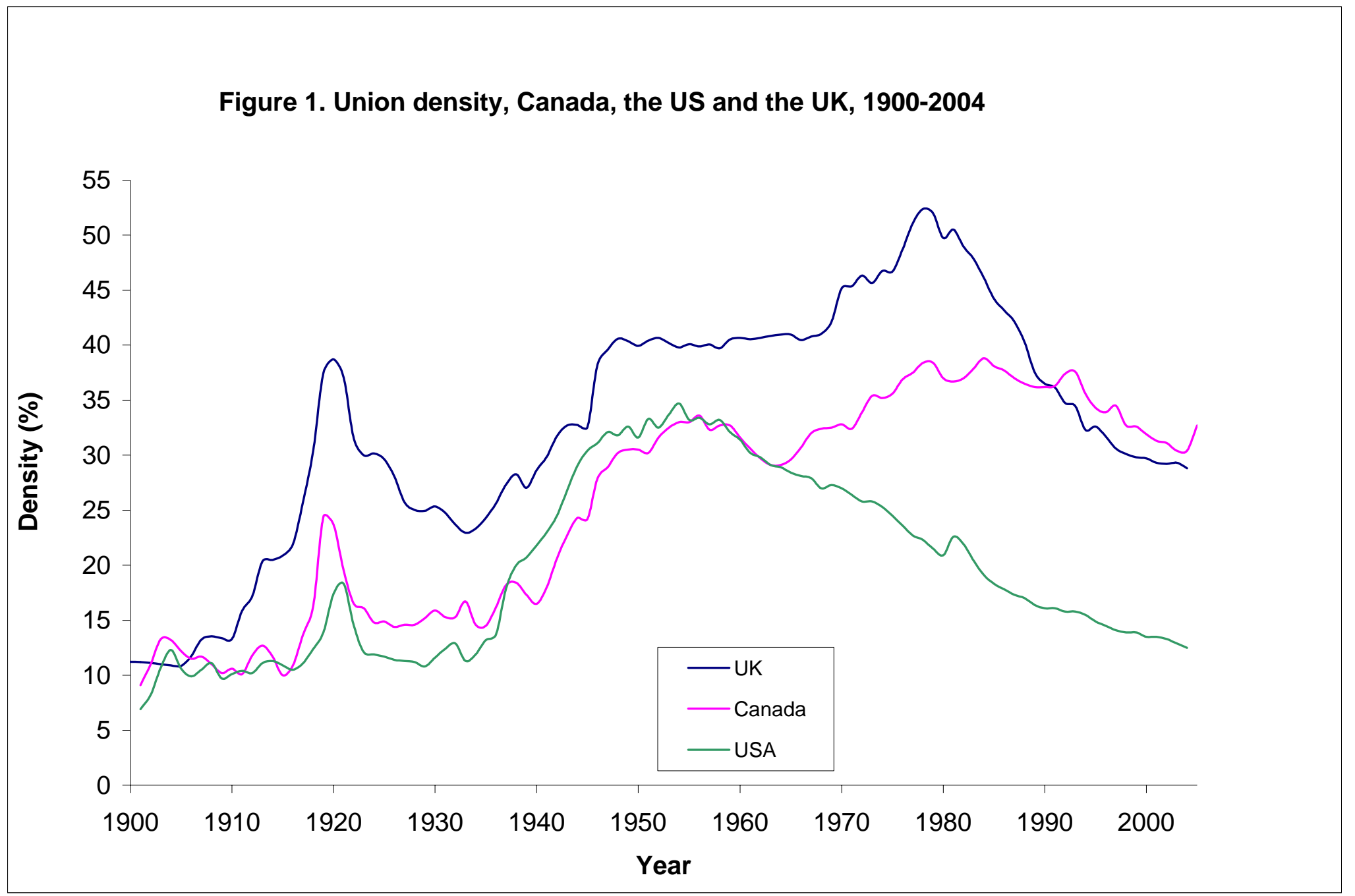

Source: Lipset and Meltz (2004); Bédard (2005) www.unionstats.com and Grainger and Holt (2005) 
Figure 2. Variation of US union membership probabilities by age

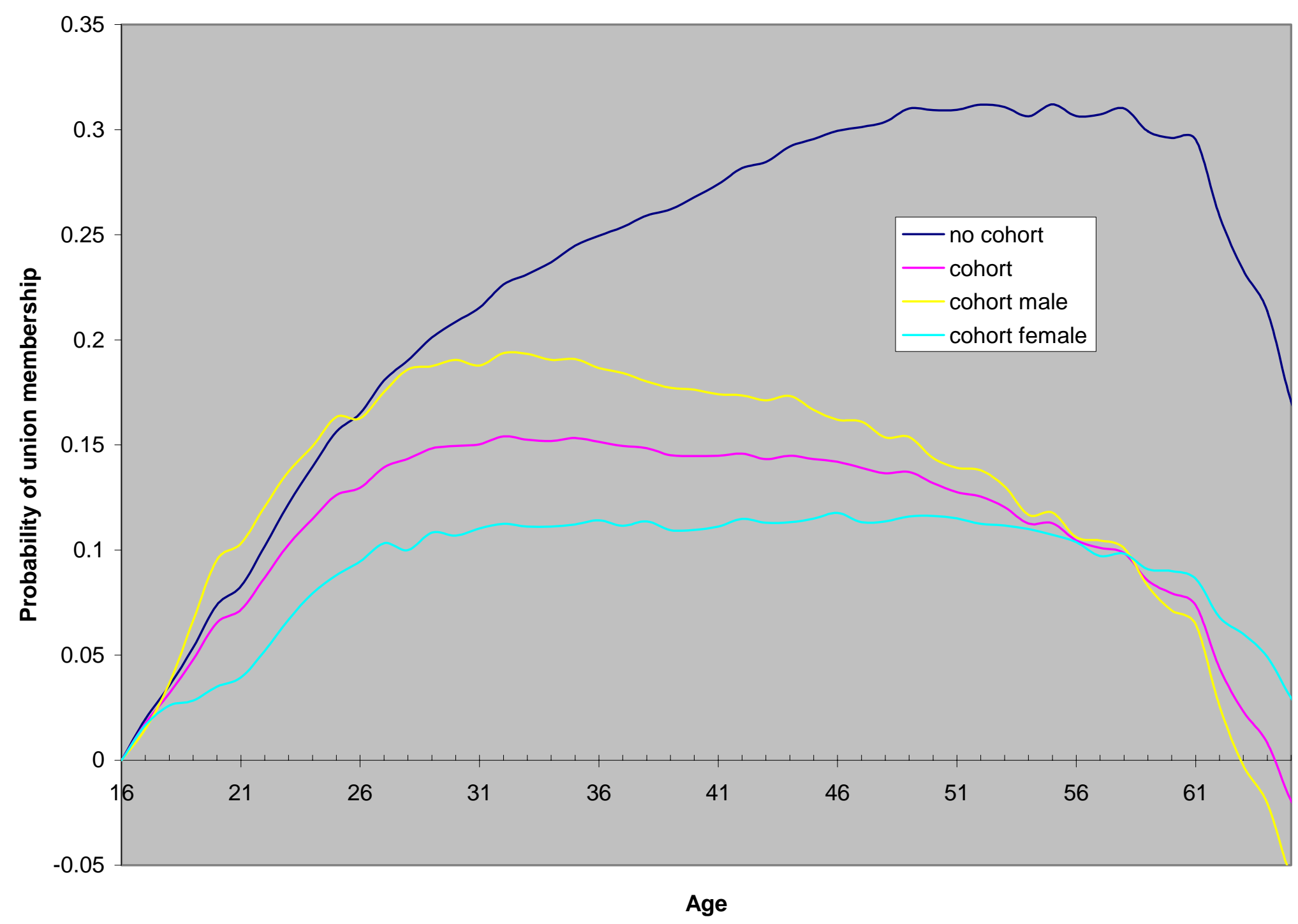


Figure 3. Cohort effects on union density, USA

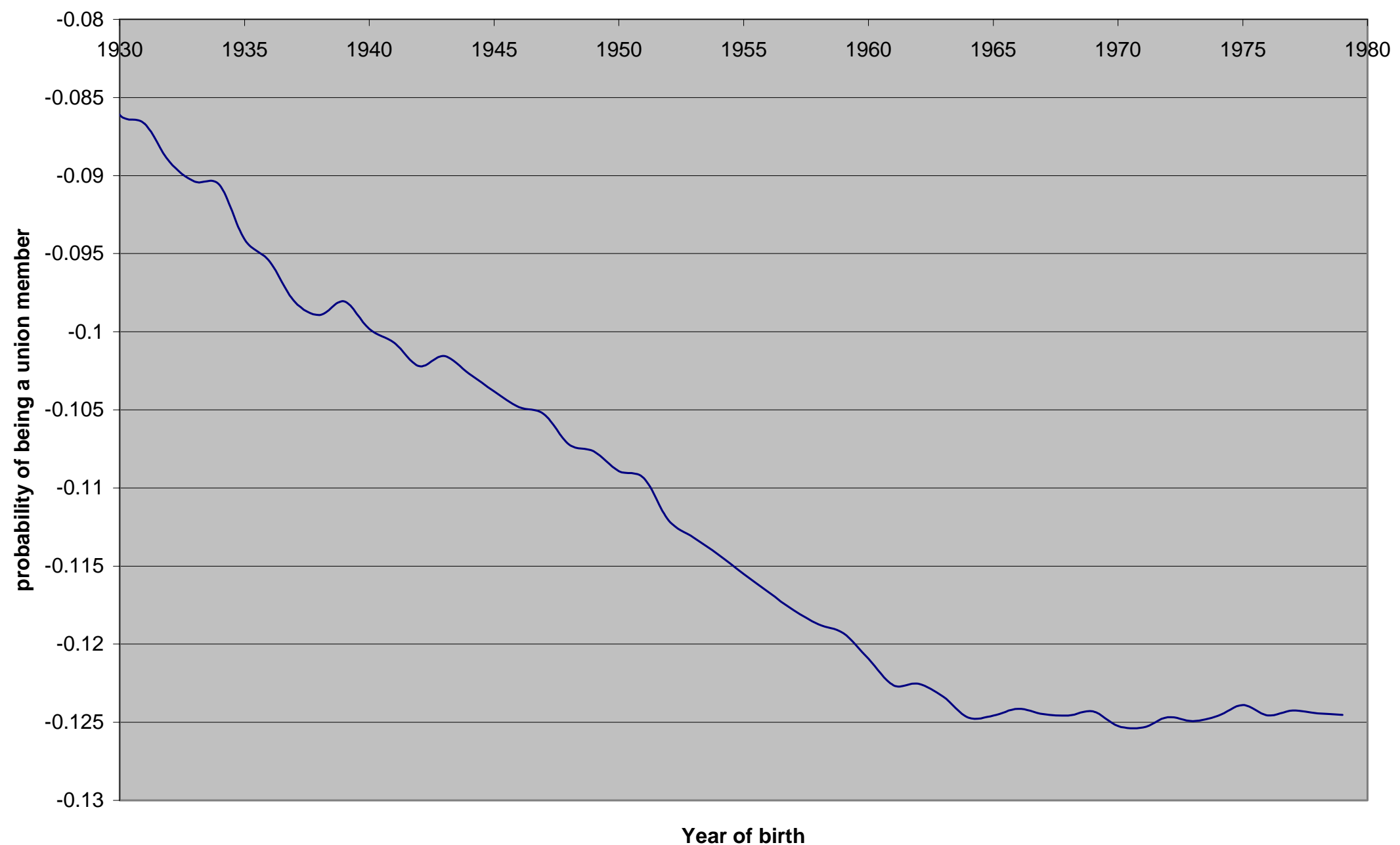




\section{$\underline{\text { References }}$}

Addison, J.T. and C. R. Belfield (2004), 'Unions and employment growth: the one constant', Industrial Relations, 43(2), April, pp. 305-322.

Addison, J.T., J.S. Heywood and X. Wei (2003), 'Unions and plant closings in Britain: new evidence from the 1990-1998 WERS', Southern Economic Journal, 64, pp. 152-170.

Aidt, T. and Z. Tzannatos (2002), Unions and Collective Bargaining. Economic Effects in a Global Environment, World Bank, Washington, DC.

Antos, J.R., Chandler. M. and W. Mellow (1980), 'Sex differences in union membership', Industrial and Labor Relations Review, 33(2), pp. 162-169.

Ashenfelter, O. and J.H. Pencavel (1969), 'American trade union growth; 1900-1960', Quarterly Journal of Economics, 83(3), pp. 434-448.

Autor, D. H. and M.G. Duggan (2003), 'The rise in the disability rolls and the decline in unemployment,' Quarterly Journal of Economics, 118(1), February, pp. 157-205

Bain, G. and P. Elias (1985), 'Trade union membership in Great Britain: an individual level analysis', British Journal of Industrial Relations, 23, pp. 71-92.

Bain, G.S. and F. Elsheikh (1976), Union Growth and the Business Cycle, Basil Blackwell, Oxford.

Bain, G. and R. Price (1983a), 'Union growth: dimension, determinants and destiny', in G. Bain (ed.), Industrial Relations in Britain. Oxford: Blackwell, pp. 3-34.

Bain, G. and R. Price (1983b), 'Union growth in Britain: retrospect and prospect", British Journal of Industrial Relations, 2(1), March, pp. 46-68.

Baker, D., A. Glyn, D. Howell and J. Schmitt (2005), 'Labor market institutions and unemployment: a critical assessment of the cross-country evidence', in D. R. Howell, editor, Unemployment and the welfare state: international perspectives on the limits of labor market deregulation, Oxford University Press.

Beaumont, P.B. and R.I.D. Harris (1995), 'Union de-recognition and declining union density in Britain', Industrial and Labor Relations Review, 48(3), pp. 389-402.

Bender, K. A., (1997), 'The changing determinants of U.S. unionism: an analysis using workerlevel data', Journal of Labor Research, 18(3), Summer, pp. 403-423.

Bertola, G., F.D. Blau and L.M. Kahn (2005), 'Labor market institutions and demographic employment patterns', working paper. 
Bennett, J.T. and B.E. Kaufman (2001), 'The future of private sector unionism in the US', Journal of Labor Research, 22(2), pp. 227-228.

Blanchard O. and J. Wolfers (2000), 'The role of shocks and institutions in the rise of European unemployment: the aggregate evidence', Economic Journal, Vol. 110, No. 462, March.

Blanchflower, D.G. (1996), 'The role and influence of unions in the OECD', a report to the Bureau of International Affairs, U.S. Department of Labor, August, downloadable from www.dartmouth.edu/ blnchflr/Projects.html

Blanchflower, D.G. (2001), 'Unemployment, well-being, and wage curves in Eastern and Central Europe', Journal of the Japanese and International Economies, 15, pp. 364-402.

Blanchflower, D.G. (2005), 'An analysis of the wage impact of trade unions in the UK public and private sectors', working paper, Dartmouth College.

Blanchflower, D.G. and D.N.F. Bell (2006), 'The Scots may be brave but they are neither healthy nor happy', NBER WP \#W11911.

Blanchflower, D.G. and A. Bryson (2003), 'Changes over time in union relative wage effects in the UK and the US revisited,' in John T. Addison and C. Schnabel, eds. International Handbook of Trade Unions. Cheltenham, UK, Edward Elgar, pp. 197-245.

Blanchflower, D.G. and A. Bryson (2004), 'What effect do unions have on wages now and would Freeman and Medoff be surprised?', Journal of Labor Research, XXV(3), Summer, pp. 383-414.

Blanchflower, D.G and R. B. Freeman (1992), 'Unionism in the U.S. and other advanced OECD Countries,' Industrial Relations, 31, Winter, 156-79; reprinted in Michael Bognanno and Morris M. Kleiner eds., Labor Market Institutions and the Future Role of Unions, Oxford: Blackwell, 1992, pp. 56-79.

Blanchflower, D.G and R.B. Freeman (1994), 'Did the Thatcher reforms change British labour market performance?', in R. Barrell (Ed.), The UK Labour Market. Comparative Aspects and Institutional Developments, Cambridge University Press.

Blanchflower, D.G, A. J. Oswald and N. Millward (1991), 'Unionism and employment behaviour', Economic Journal, July, pp. 815-834

Blandon, J and S. Machin (2003), 'Cross-generation correlations of union status for young people in Britain', British Journal of Industrial Relations, September, 41(3), pp. 391-415.

Blundell, R., D. Card and R. Freeman (eds.) (2003), Seeking a Premier League Economy, NBER and University of Chicago Press.

Booth, A. (1986), 'Estimating the probability of trade union membership: a study of men and women in Britain', Economica, 53, pp. 41-61. 
Bryson, A, (2003), 'Employee desire for unionization in Britain and its implications for union organizing', Working Paper, Policy Studies Institute, London.

Bryson, A, (2004a), 'Unions and employment growth in British workplaces in the 1990s: a panel analysis', Scottish Journal of Political Economy, September, 51(4), pp. 477-506.

Bryson, A, (2004b), 'Unions and workplace closure in Britain, 1990-1998', British Journal of Industrial Relations, 42(2), June, pp, 282-302.

Bryson, A, (2006), Union Free-Riding in Britain and New Zealand, Centre for Economic Performance, Discussion Paper No 713, January 2006, London School of Economics.

Bryson, A, and R.B. Freeman (2006), 'Worker Needs and Voice in the US and the UK', NBER WP \#

Bryson, A, and R. Gomez (2005), 'Why have workers stopped joining unions? Accounting for the rise in never-membership in Britain', British Journal of Industrial Relations,43(1), pp. 67-92.

Borland, J. and S. Ouliaris (1994), 'The determinants of Australian trade union membership', Journal of Applied Econometrics, 9, pp. 453-468.

Bureau of Labour Statistics (2005), 'Union members in 2005', UDDL 06-99 downloadable at www.bls.gov/news.release/pdf/union2.

Card, D, T. Lemieux and C. Riddell (2003), 'Unions and the wage structure', in John T. Addison and C. Schnabel, eds. International Handbook of Trade Unions. Cheltenham, UK: Edward Elgar, pp. 246-292.

Card, D, T. Lemieux and C. Riddell (2004), 'Unions and wage inequality', Journal of Labor Research, Fall, Vol. 25 Issue 4, pp. 519-562.

Carruth, A. and R. Disney (1988), 'Where have two million union members gone?,' Economica, 55, pp. 1-20.

Carruth, A. and C. Schnabel (1990), 'Empirical modeling of trade union growth in Germany, 1956-1986: traditional versus cointegration and error correction methods', Weltwirtschaftliches Archiv, 126(2), pp. 326-46.

Charlwood, A. (2002), 'Why do non-union employees want to unionize? Evidence from Britain', British Journal of Industrial Relations, 40(3), September, pp. 463-491.

Christie, V, (1992), 'Union wage effects and the probability of union membership', Economic Record, March, pp. 43-56.

Deery S. and H. De Cieri (1991), 'Determinants of trade union membership in Australia', British Journal of Industrial Relations, 29(1), pp. 59-74. 
DiNardo, J. and D.S. Lee (2004), 'Economic impacts of new unionization on private sector employers', Quarterly Journal of Economics, 119(4), November, pp. 1383-1441

Disney, R. (1990), 'Explanations of the decline in trade union density in Britain: an appraisal', British Journal of Industrial Relations, 28: 165-77.

Disney, R., Gosling, A. and S. Machin (1994), 'British unions in decline: an examination of the 1980s fall in trade union recognition', Industrial and Labor Relations Review, 48, pp. 403-19.

Disney, R., Gosling, A. and S. Machin (1995), 'What has happened to union recognition in Britain?', Economica, 63, pp. 1-18.

Elias, P. (1996), 'Growth and decline in trade union membership in Great Britain: evidence from work histories', in Trade Unionism in Recession, edited by D. Gallie, R. Penn and M. Rose, Oxford University Press, Oxford.

Farber, H.S. (1985), 'The extent of unionization in the United States', in Kochan, T. (ed.) Challenges and Choices Facing American Labor, MIT Press, Cambridge, MA, pp. 14- 44.

Farber, H.S. (1990), 'The decline of unionization in the United States: what can be learned from recent experience?', Journal of Labor Economics, 8(1, pt.2), pp. S75-S105.

Farber, H.S., and A.B. Krueger (1993), 'Union membership in the United States: the decline continues', in Employee Representation; Alternatives and Future Directions, edited by B. Kaufman and M. Kleiner, Industrial Relations Research Association.

Fiorito, J., L.P. Stepina, and D.P. Bozeman (1996), 'Explaining the unionism gap: public-private sector differences in preferences for unionization', Journal of Labor Research, 27(3), pp. 463478.

Flanagan, R.J. (2005), 'Has management strangled U.S. unions?', Journal of Labor Research, 26(1), pp. 33-64.

Förster, M. and M.M. d'Ercole (2005), 'Income distribution and poverty in OECD countries in the second half of the 1990s', OECD Social, Employment and Migration Working Papers, OECD, $10^{\text {th }}$ March, WP \#22.

Freeman, R.B. (1986), 'Unionism comes to the public sector', Journal of Economic Literature, March, 24(1), pp. 41-86.

Freeman, R.B. (1988), 'Contraction and expansion: the divergence of private sector and public sector unionism in the United States', Journal of Economic Perspectives, 2(2), Spring, pp. 6388. 
Freeman, R.B. (2005a), 'What Do Unions Do? The 2004 M-Brane Stringtwister Edition' Journal of Labor Research, Fall , Vol. 26 Issue 4, pp. 641-668.

Freeman, R.B. (2005b), 'Labour market institutions without blinders: the debate over flexibility and labour market performance', NBER Working Paper \#11286.

Freeman, R.B. and M. Kleiner (1999), 'Do unions make enterprises insolvent?', Industrial and Labor Relations Review, 52, pp. 510-527.

Freeman, R.B. and J. Pelletier (1990), 'The impact of industrial relations legislation on British union density', British Journal of Industrial Relations, 29(2), pp. 141-164.

Freeman, R.B. and M.E. Rebick (1989), 'Crumbling pillar? Declining union density in Japan', Journal of the Japanese and International Economies, 3(4), pp. 578-605.

Freeman, R.B. and J. Rogers (1999), What Workers Want, ILR Press, Ithaca, NY.

Glyn, A., D.R. Howell, and J. Schmitt (2006), 'Labor Market Reforms and Unemployment: Does the Evidence tell an Orthodox Tale?', working paper, January, downloadable at http://www.newschool.edu/cepa/research/rwg_employment-protection.htm

Grainger, H. and T. Holt (2005), 'Trade union membership, 2004', Department of Trade and Industry, April. Downloadable at www.dti.gov.uk/er/emar/tradeunion_membership2004.pdf

Green, F. (1990), 'Trade union availability and trade union membership in Britain', The Manchester School, LVIII(4), December, pp. 378-394.

Green, F. (1992), 'Recent trends in British trade union density: how much of a compositional effect?', British Journal of Industrial Relations, 30: 445-58.

Haberfeld, Y. (1995), 'Why do workers join unions? The case of Israel', Industrial and Labor Relations Review, 48(4), pp. 656-670.

Heap, D. (2005), 'Characteristics of people employed in the public sector', Labour Market Trends, December, pp. 489-500. Downloadable at www.statistics.gov.uk/articles/labour_market_trends/characteristics_Dec05.pdf

Hicks, S. (2005), 'Trends in public sector employment', Labour Market Trends, December, pp. 477-488 downloadable at www.statistics.gov.uk/articles/labour_market_trends/pub_sec_trend.pdf

Hines, A.G. (1964), 'Trade unions and wage inflation in the United Kingdom, 1893-1961', Review of Economic Studies, 31, pp. 221-251.

Hirsch, B.T. (2004), 'What do unions do for economic performance', Journal of Labor Research, XXV(3), Summer, pp. 415-455, 
Hirsch, B.T. and D.A. Macpherson (2002), Union membership and earnings data book: compilations from the Current Population Survey, The Bureau of National Affairs Inc.

Hirsch, B.T. and D.A. Macpherson (2003), 'Union membership and coverage database from the Current Population Survey: note’, Industrial and Labor Relations Review, 56(2), January, pp.349-354.

Hirsch, B.T. and E.J. Schumacher (2004), 'Match bias in wage gap estimates due to earnings imputation', Journal of Labor Economics, July, 22(3), pp. 689-722.

Hirsch, B.T. and M. Berger (1984), 'Union membership determination and industry characteristics', Southern Economic Journal, 50, pp. 665-679.

International Labour Organisation (2005), Trade Union Membership database, Bureau of Statistics, Geneva, Switzerland

Inter-American Development Bank (2003), Good Jobs Wanted, Baltimore, MD: Johns Hopkins Press.

Katz, L., G. Loveman and D.G. Blanchflower (1995), 'A comparison of changes in the structure of wages in four OECD countries', in Differences and Changes in Wage Structures edited by Larry Katz and Richard Freeman, University of Chicago Press and NBER, pp. 25-65.

Kelly, J. (2005), 'Social movement theory and union revitalization in Britain' in Trade Unions, Resurgence or Demise, edited by S. Fernie and D. Metcalf, Routledge, Oxon.

Kleiner, M. M. (2002), 'Intensity of management resistance: understanding the decline of unionization in the private sector', Journal of Labor Research, 22(3), pp519-540.

Kleiner, M. M. (2005), 'Follow the leader: are British unions tracking the US decline?' in S. Fernie and D. Metcalf (eds.), Trade Unions Resurgence or Demise?, Routledge, Abingdon.

Kokkelenberg, E.C. and D.R. Sockell (1985), 'Union membership in the United States, 19731981', Industrial and Labor Relations Review, 38(3), July, pp.497-543.

Kumar, P. and B. Dow (1986), 'Econometric analysis of union membership growth in Canada, 1935-1981', Relations Industrielles, 41, pp. 236-253.

Layard, P. R. G., Nickell, S., and Jackman, R. (1991), Unemployment: Macroeconomic Performance and the Labour Market, Oxford University Press, Oxford.

Leonard, J. (1992), 'Unions and employment growth', Industrial Relations, 33, October, pp. 8094. 
Lindsay, C. (2003), 'A century of labour market change: 1900-2000', Labour Market Trends, 111(3), pp. 133-143 downloadable at www.statistics.gov.uk/downloads/theme_labour/LMT/March03_revised/pdf

Lipset, S.M. and N.H. Meltz (2004), The Paradox of American Unionism. Why Americans Like Unions More Than Canadians But Join Much Less, Cornell University Press.

Long, R.J. (1993), 'The impact of unionization on employment growth of Canadian companies', Industrial and Labor Relations Review, 46(4), pp. 691-703.

Lora, E. A. and C. Pagés-Serra (2003), 'Labor market regulations and institutions', in Economic and Social Progress in Latin America - 2004 Report, October, Inter-American Development Bank,

McDonald, C., (1990), 'U.S. union membership in the 1990s and beyond: a trade unionist's perspective', mimeo, AFL-CIO, Washington D.C..

Machin, S. (1995), 'Plant closures and unionization in British establishments', British Journal of Industrial Relations, 33(1), pp. 55-68.

Machin, S. (2000), 'Union decline in Britain', British Journal of Industrial Relations, 38, pp. 63145.

Machin, S. (2004), 'Factors of convergence and divergence in union membership', British Journal of Industrial Relations, 42(3), September, pp. 423-428.

Maloney, T., and Savage, J. (1996), 'Labour markets and policy', in A Study of Economic Reform: The Case of New Zealand, edited by B. Silverstone, A. Bollard, and R. Lattimore, Elsevier Science, Amsterdam.

Mason, R. and P. Bain (1993), 'The determinants of trade union membership in Britain: a survey of the literature', Industrial and Labor Relations Review, 46, pp. 332-51.

Metcalf, D. (2005), 'Trade unions: resurgence or perdition? An economic analysis', in Trade Unions, Resurgence or Demise, edited by S. Fernie and D. Metcalf, Routledge, Oxon.

Millward, N and M. Stevens (1988), 'Union density in the regions', Employment Gazette, May, pp. 286-295

Morissette, R., G. Schellenberg and A. Johnson (2005), 'Diverging trends in unionization', Perspectives on Labour and Income, 6(4), April, Statistics Canada, pp. 5-12.

Nickell, S., L. Nunziata, and W. Ochel (2005), 'Unemployment in the OECD since the 1960s: What Do We Know?', The Economic Journal 115, January, pp. 1-27, Royal Economic Society.

Nickell, S. (1997), “Unemployment and Labor Market Rigidities: Europe versus North America', Journal of Economic Perspectives, 11(3), Summer, pp. 55-74. 
Neumann, G. and E. Rissman (1984), 'Where have all the union members gone?', Journal of Labor Economics, 2(2), pp. 175-192.

OECD (1994a). OECD Jobs Study, Evidence and Explanations, Part I: Labor Market Trends and Underlying Forces of Change, Paris: OECD.

OECD (1994b) OECD Jobs Study, Evidence and Explanations, Part II: The Adjustment

Potential of the Labor Market. Paris: OECD.

OECD (1999), Implementing the OECD Jobs Strategy: Assessing Performance and Policy, Paris: OECD.

OECD (2004), 'Wage setting institutions and outcomes', Employment Outlook, 2004, pp, 127181.

OECD (2005a), 'OECD Jobs Study: Lessons from a decade's experience. Main report', Working Paper, OECD, $19^{\text {th }}$ December, Paris.

OECD (2005b), 'OECD Jobs Strategy: Lessons from a Decade's Experience, Background Report No. 1 - Reassessing the Role of Policies and Institutions for Labour Market Performance: A Consolidated Analysis, Working Paper, OECD, $19^{\text {th }}$ December, Paris.

van Ours, J.C. (1992), 'Union growth in the Netherlands, 1961-1989', Applied Economics, 24, pp. 1059-1066.

Payne, J. (1989), 'Trade union membership and activism among young people in Great Britain', British Journal of Industrial Relations, 25(2), pp. 267-274.

Pedersen, P.J. (1982), 'Union growth in Denmark', Scandinavian Journal of Economics, 84, pp. 583-592.

Pencavel, J. (1971), 'The demand for union services: an exercise', Industrial and Labor Relations Review, 24, pp. 180-90.

Pencavel, J. (2004), 'The surprising retreat of union Britain', in Seeking a Premier League Economy, edited by R. Blundell, D. Card and R. Freeman, NBER and University of Chicago Press.

Pencavel, J. (2005), 'Unionism viewed internationally', Journal of Labor Research, XXVI(1), Summer, pp. 65-97.

Price, R. and G.S. Bain (1983), 'Union growth in Britain: retrospect and prospect', British Journal of Industrial Relations, 21, pp. 46-68. 
Reder, M. (1988), 'The rise and fall of unions: the public and private sectors', Journal of Economic Perspectives, 2(2), pp. 89-110.

Richardson, R. and S. Catlin (1979), 'Trade union density and collective agreement patterns in Britain', British Journal of Industrial Relations, 17, pp. 376-385.

Riddell, C. (1993), 'Unionization in Canada and the United States: A tale of two countries' in Small Differences That Matter: Labor Markets and Income Maintenance in Canada and the United States, edited by D. Card and R.B. Freeman, University of Chicago Press and National Bureau of Economic Research Comparative Labor Markets Series. Chicago and London.

Riley, N. (1997), 'Determinants of union membership: a review', Labour, 11, pp. 265-301.

Roche, W.K. and J. Larragy (1990), 'Cyclical and institutional determinants of annual trade union growth and decline in Ireland. Evidence from the DUES data series', European Sociological Review, 6, pp. 48-72.

Sapsford, D. (1984), 'The determinants of trade union growth in the Irish Republic: an econometric study', Economic and Social Review, 15, pp. 305-323.

Schnabel, C. (2003), 'Determinants of trade union membership', in J. Addison and C. Schnabel (eds.), The International Handbook of Trade Unions, Cheltenham: Edward Elgar, pp. 13-43.

Schnabel, C. and J. Wagner (2003), 'Determinants of union membership in 18 EU countries: evidence from micro data', IZA DP \# 1464, Institute for the Study of Labor, University of Bonn, Germany

Sharma, B. (1989a), 'Korean trade union growth during the period 1962-1984', Economics Letters, 31(1), November, pp. 105-108.

Sharma, B. (1989b), 'Union growth in Malaysia and Singapore', Industrial Relations, 28(3), pp. 446-458.

Sharma, B. and P. Sephton (1991), 'The Determinants of Union Membership Growth in Taiwan', Journal of Labor Research; 12(4), Fall, pp. 429-37.

Shister, J. (1953), 'The logic of union growth', Journal of Political Economy, LXI, pp. 413-433.

Sharpe, I.G. (1971), 'The growth of Australian trade unions, 1907-1969', Journal of Industrial Relations, 13, pp. 138-156.

Stewart, M.B. (1983), 'Relative earnings and individual union membership in the United Kingdom', Economica, 50, no. 198, pp. 111-125. 
Swidinsky, D. (1974), 'Trade union growth in Canada: 1911-1970', Relations Industrielles, 29, pp. 435-451

Visser, J. (2002), 'Why fewer workers join unions in Europe', British Journal of Industrial Relations, 40: 403-30.

Visser, J. (2003), 'Unions and unionism around the world', in J. Addison and C. Schnabel (eds.), The International Handbook of Trade Unions, Cheltenham: Edward Elgar, pp. 366-413.

Visser, J. (2006), 'Union membership statistics in 24 countries', Monthly Labor Review, January, pp. 38-49.

Weiler, P. (1990), Governance of the Workplace, Harvard University Press, Cambridge, MA.

World Bank (2003), 'Economies perform better in coordinated labor markets', February $12^{\text {th }}$, http://web.worldbank.org/WBSITE/EXTERNAL/NEWS/0,,contentMDK:20091655 menuPK:34 463 pagePK:34370 piPK:34424 theSitePK:4607,00.html 
Appendix Table 1. Union density equations - UK

\begin{tabular}{|c|c|c|c|c|c|c|c|}
\hline & (1) & (2) & (3) & (4) & (5) & (6) & (7) \\
\hline \multirow[t]{2}{*}{ Male } & -.0074 & .0085 & .0767 & .0575 & .0635 & .0801 & .0575 \\
\hline & $(1.75)$ & $(1.90)$ & $(16.22)$ & $(11.45)$ & (12.51) & (17.88) & (12.80) \\
\hline \multirow[t]{2}{*}{ Age } & No & .0413 & .0348 & .0323 & .0299 & No & .0254 \\
\hline & & (34.77) & $(28.73)$ & $(26.88)$ & $(24.53)$ & & $(24.34)$ \\
\hline \multirow[t]{2}{*}{$\mathrm{Age}^{2}$} & No & -.00043 & -.00037 & -.00034 & -.00031 & No & -.00026 \\
\hline & & $(30.21)$ & $(25.63)$ & $(23.74)$ & $(21.71)$ & & $(21.30)$ \\
\hline Self-employed & No & No & No & No & No & No & $\begin{array}{c}-.1114 \\
(17.23)\end{array}$ \\
\hline Race dummies & No & 5 & 5 & 5 & 5 & No & 5 \\
\hline Region of residence dummies & No & 19 & 19 & 19 & 19 & No & 19 \\
\hline Schooling dummies & No & 45 & 45 & 45 & 45 & No & 45 \\
\hline Industry dummies & No & No & No & 59 & 59 & No & 59 \\
\hline Private sector dummy & No & No & Yes & No & Yes & Yes & Yes \\
\hline Employees only & Yes & Yes & Yes & Yes & Yes & Yes & No \\
\hline $\mathrm{N}$ & 46,798 & 46,788 & 46,633 & 46,754 & 46,606 & 46,643 & 53,729 \\
\hline $\mathrm{R}^{2}$ & .0001 & .0563 & .1818 & .1871 & .2249 & .1363 & .2334 \\
\hline
\end{tabular}

